Copyright $($ Emerald Publishing Limited 2019. This author accepted manuscript is deposited under a Creative Commons Attribution Non-commercial 4.0 International (CC BY-NC) licence. This means that anyone may distribute, adapt, and build upon the work for non-commercial purposes, subject to full attribution. If you wish to use this manuscript for commercial purposes, please contact permissions@emerald.com.

\title{
Corporate Governance in Malaysia: A Systematic Literature Review and Research Agenda
}

\author{
${ }^{* 1}$ Saleh F. A. Khatib \\ Aziman Hashim International Business School, \\ Universiti Teknologi Malaysia, Johor Baru 81310, Malaysia. \\ https://orcid.org/0000-0001-7652-4191 \\ Saleh.f.info@gmail.com
}

\begin{abstract}
${ }^{2}$ Ahmed A Elamer
Brunel Business School, Brunel University London, Kingston Lane, Uxbridge, London, UB8 3PH UK

Department of Accounting, Faculty of Commerce, Mansoura University, Mansoura, Egypt https://orcid.org/0000-0002-9241-9081

ahmed.a.elamer@gmail.com
\end{abstract}

${ }^{3}$ Dewi Fariha Abdullah

Aziman Hashim International Business School,

Universiti Teknologi Malaysia, Johor Baru 81310, Malaysia.

https://orcid.org/0000-0002-7799-6972

dewifariha@utm.my

${ }^{4}$ Saddam A. Hazaea

School of Accounting,

Yunnan University of Finance and Economics, Kunming, China

Sadhi792@gmail.com 


\title{
The Development of Corporate Governance Literature in Malaysia: A Systematic Literature Review and Research Agenda
}

\begin{abstract}
:
Purpose: This study provides a comprehensive review of the existing literature on corporate governance aspects of the Malaysian market. It offers insights into the phases of Malaysian corporate governance, identifies crucial gaps in the literature and outlines an agenda for impending research.
\end{abstract}

Design/methodology/approach: Following a systematic literature review approach, a final sample of 125 studies from Scopus and Web of Science databases were utilized in this study. These studies were selected based on quality assessment criteria. Then, the sample literature was evaluated in terms of journals, methodology, theories, modelling, research outcomes and corporate governance characteristics.

Findings: Our results show that there is a growing interest among researchers to further explore corporate governance aspects in Malaysia due to the continuous development of the Malaysian corporate governance codes. Likewise, the review reveals that the majority of prior studies are quantitative and were carried out utilizing archived data from non-financial firms. Also, the existing literature has primarily focused on the outcomes of corporate governance, especially firm performance.

Research limitations/implications: Overall, our results show that there is ample room for future research. The present paper identifies a number of methodological problems and concerns, and discusses the implications of these problems, while also providing recommendations for future research. The main caveat is that we use scholarly papers published in academic journals only, but this approach offers us with opportunities for considerable further developments.

Originality/value: This study contributes to the literature by being the first of its kind to concentrate on the Malaysian context. It provides a comprehensive knowledge assessment of the Malaysian corporate governance research and offers advice regarding improvements in research, policy and practice by identifying possible knowledge gaps. Consequently, our study provides a cohesive story of the past and a road map for future research on Malaysian corporate governance.

Keywords: Corporate Governance, Firm Performance, Corporate Social Responsibility, Earnings Management, Disclosure Quality, Malaysia 


\section{Introduction}

The Securities Commission Malaysia has defined corporate governance (CG) as "the process and structure used to direct and manage the business and affairs of the company towards promoting business prosperity and corporate accountability with the ultimate objective of realising long-term shareholder value while taking into account the interest of other stakeholders" (MCCG, 2017). Similarly, Shleifer and Vishny (1997, p. 737) state that "Corporate governance deals with the ways in which suppliers of finance to corporations assure themselves of getting a return on their investment. How do the suppliers of finance get managers to return some of the profits to them? How do they make sure that managers do not steal the capital they supply or invest it in bad projects? How do suppliers of finance control managers?".

Recent corporate scandals suggest that weak corporate governance leads to fragile institutions and exposes them to severe crises (Al Amosh and Khatib, 2021; Hazaea et al., 2021a). Malaysian corporations are not an exception to that vulnerability, given they were severely affected by both the 1997-1998 Asian financial crisis (AFC) and 2007-2009 Global financial crisis (GFC), largely as a result of weak corporate governance systems. Thus, corporate governance has witnessed enormous developments over recent decades (Alnabsha et al., 2018; Alshbili et al., 2019; Bufarwa et al., 2020; Elamer et al., 2018, 2021). For instance, Malaysia initiated the Malaysian Code on Corporate Governance (MCCG) in 2000 to improve the principles, guidelines and governance practices within the market to prevent such crises in future (MCCG, 2007). Consequently, this has led to efforts to rectify and overhaul the entire corporate sector in Malaysia. The introduction of MCCG was followed by an overwhelming number of studies on Malaysian corporate governance. These studies have confirmed the existence of a variety of previously explored research themes. Prior research, however, has provided mixed empirical evidence relating to the impact of corporate governance on firm performance (Haniffa and Hudaib, 2006), dividend policy (Benjamin, 2015), corporate social responsibility (Ho and Taylor, 2013), and financial reporting quality (Mohamad-Nor et al., 2010).

Despite inconclusive findings in prior empirical studies, and the growing interest in the field, there have been no serious efforts to systematically review the literature related to CG in Malaysia (Annuar, 2014), and this gap is the key motivation for our study. The limited set of reviews on the Malaysian context have placed great focus on certain governance 
attributes, such as ownership mechanisms (Kim et al., 2012), leadership structure (Yasser and Al Mamun, 2016), family control (Ng et al., 2014), and audit committee (Rahim et al., 2015), while other scholars have concentrated on the general development of CG in the Malaysian market (Alnasser, 2012; Liew, 2007; Rachagan and Kuppusamy, 2013). Additionally, Shariff et al. (2018) conducted a review on CG best practices of small tourism firms, and Khatib et al. (2020a) presented an evaluation of the relationship between several governance attributes and capital structure. However, most of these reviews were specific to a single governance mechanism (i.e., audit committee) or outcomes (i.e., capital structure), and none considered all aspects of the corporate governance literature. Thus, taking this as a valuable opportunity, we present this paper to answer the following questions.

RQ1: What does the overall literature show regarding the current state of corporate governance research?

RQ2: Which themes related to corporate governance have been investigated?

RQ3: Which governance attributes are used by scholars to study corporate governance?

RQ4: What are the research gaps and potential future research directions for corporate governance in Malaysia?

To address these questions, we provide a systematic literature review and comprehensive analysis of the current state-of-the-art literature and do not limit our investigation to particular governance mechanisms, outcomes, or periods (Gonzales-Bustos and Hernández-Lara, 2016; Li et al., 2020). It has been suggested that systematic literature reviews help to synthesize research in a reproducible, transparent, and systematic manner to identify significant gaps, contribute to theory development, and provide directions for future research (Endenich and Trapp, 2020; Pedrini and Ferri, 2019), hence the need for such a study in the context of Malaysian corporate governance.

This research contributes to the literature by being the first of its kind to focus on the Malaysian market. The study provides an up-to-date systematic assessment of the existing research that addresses Malaysian corporate governance. Unlike the traditional approach of a "narrative" review, this study evaluates the relevant research articles using a systematic approach while also offering multiple recommendations for future research. Using a large number of prior studies (i.e., 125 articles), the present paper describes key theoretical and methodological trends in recent research on Malaysian governance codes. It also adds to existing knowledge by offering insight into the recent developments in the broader field of corporate governance research. 
The review illustrates that there has been a growing number of studies over the past years and reveals that CG-related research in the Malaysian context has only focused on governance outcomes, especially firm performance while neglecting the antecedent of governance mechanisms. This growth is attributed to (i) the financial crisis, (ii) the failure of several companies in the last two decades, and (iii) the continuous development of the MCCG. It is also expected that more research will be published in the future that explores the impact of the Covid-19 global pandemic on various aspects of corporate governance. Despite this growing interest among scholars, our study shows that there are insufficient studies that used qualitative or mixed methods. The findings also suggest that resource dependency theory and agency theory are the key theoretical perspectives in the sample literature, while a limited number of studies applied cultural and behavioural theories. Exploring the cultural or behavioural theories of corporate governance might also help researchers develop our understanding and help better explain the diverse functions of corporate governance aspects, especially from a culturally diverse country like Malaysia. Overall, despite the existing body of literature having significantly contributed to significant advances in our knowledge on Malaysian corporate governance, there is ample room for future research to contribute to the extant literature.

The remainder of this study is structured as follows. Section two presents the research method used. Section three summarizes the findings, followed by the fourth section, where we provide a brief discussion and suggest several avenues for future research. Finally, we provide a conclusion of our paper in the fifth section.

\section{Research methodology}

We adopted the systematic review methodology due to its effectiveness in comprehensively gauging a limited field of study (Hazaea et al., 2021b; Khatib et al., 2021a; Zamil et al., 2021). This approach differs from that of conventional reviews in that it is transparent and allows for the unification of research and practitioner communities, leading to a better overall synthesis of the available information (Pedrini and Ferri, 2019). A systematic literature review helps to synthesize research in a reproducible, transparent, and systematic manner to identify significant gaps, contribute to theory development, and provide directions for future research (Endenich and Trapp, 2020; Pedrini and Ferri, 2019). We employed a five-step approach to identify and evaluate the quality of papers involved, namely keywords 
identification, documents collection, assessment of the quality, extraction of the data, and data synthesis (E-Vahdati et al., 2019; Khatib et al., 2021b; Walker, 2010).

For the literature sample, given that a systematic review of the literature related to $\mathrm{CG}$ in Malaysia is our primary objective, the keywords related to the concepts of interest in this study were divided into two groups. The first group consisted of keywords related to the context under investigation 'Malaysia*', while the second group involved other keywords related to the theme of corporate governance. Unlike some studies that use precise keywords such as 'corporate governance', 'board of directors', or 'board diversity' (Gonzales-Bustos and Hernández-Lara, 2016; Rasel and Win, 2020), we followed Li et al. (2020), who used a broad keyword search terms including govern*, director*, and board*. Although these terms result in a large number of documents, these keywords helped compile a comprehensive list of published research articles relevant to this review, and helped avoid excluding important studies.

To identify the relevant research documents, we searched the Web of Science (WoS) and Scopus databases for articles that include the following keywords in the title, abstract, and keywords: ("Malaysia*”) AND ("govern*” OR “director*” OR "board*”). These databases were chosen as they provide a comprehensive list of published documents from different disciplines and include citation counts, which is important information for quality assessment (Cruz-González et al., 2021; Linnenluecke et al., 2020; Wan Sulaiman and Mustafa, 2020). In July 2020, the search strings initially hit a sample of 10141 documents (7374 papers from Scopus and 2767 articles from WoS). After checking for duplication and articles with missing data, this number was reduced to 8150 documents, which were then subject to title and abstract evaluation. Then, we screened the titles and abstracts of articles and excluded papers that either did not explicitly address CG aspects or did not specifically investigate the Malaysian context. This process resulted in 1348 articles that were then subject to a quality assessment. Since this study used broad keywords to search the literature, it was not surprising that a large number of the sample literature was not related to the concepts of interest in this review.

In the quality assessment step, we assessed the quality of the published documents identified in the previous stage based on the number of citations. The quality assessment refers to the most cited articles in each pre-identified period that were included in the content analysis. It should be noted that the citation frequency of an article depends on the date of 
publication and the content of the article. For example, old documents have more opportunities to attract citations compared to new papers. For this reason, it was essential to use the date of publication as a base to group the documents into three categories and each category was subject to different criteria during the quality assessment (Walker, 2010). Category 1: 2008-2017, category 2: 1987-2007, and category 3: 2018-2020. The final sample from these groups comprises a total of 125 articles (discussed further below).

Category 1 involved all published documents between the years 2008 and 2017. Following Walker (2010), these specific ten years were chosen since the number of research articles had increased rapidly during this period. All articles in this category were subject to the citation criterion assessment. To pass the citation quality test, an article should have an average of two citations per year (citation matrix provided by Scopus or WOS). The final sample from this category hit a set of 88 articles.

Category 2 involved all documents from the earliest articles published between 19872007. The minimum requirement to pass the quality assessment in this set are two citations per year or being published in one of the most productive fifteen journals in the area ${ }^{1}$. These journals represented $58 \%$ of the documents selected in category 1 (see Table I). In total, twenty-one articles were identified in this group.

Category 3 consisted of sixteen articles that had been published between the years 2018 and 2020 in one of the leading fifteen journals. Since these recently published documents had not yet had time to accumulate citations, citation tests were not performed on this group.

\section{[Insert Table I here]}

\section{Results}

We followed the approach used by several studies and concentrated on the evaluation of seven areas: research questions, modelling, data geography, theories, research methods, journal outlets, and concepts under study (Khatib et al., 2021a; Li et al., 2020; Nielsen, 2010; Schiehll and Martins, 2016; Tenzer et al., 2017). These themes were chosen because they have a proven ability to facilitate fully exhaustive reviews. To address these themes, we first analysed the year frequency of the publication, research methodology, questions, and data

\footnotetext{
1 The leading 15 journals were determined by using the 88 documents in Category 1.
} 
geography in terms of being cross-sectional studies or based only in the Malaysian context. Second, we provided a more in-depth evaluation by reviewing the theories, models, and concepts found in the sample literature.

In terms of publication trends, the earliest research papers identified in the sample literature dated as early as 2002. Since then, there has been a substantial increase in the number of scientific articles on CG that cover the Malaysian context (see Figure 1). It should be noted that the majority of studies were published between 2010 and 2018. This might be because of the 2007-2009 GFC, which was attributed to poor corporate governance and insufficient government enforcement actions that were taken by the Malaysian authorities in 2000, 2007, 2012, and 2017. Overall, the cumulative research trend indicates that scholars are increasingly becoming interested in Malaysian CG research. It is also expected that we should see more research exploring the impact of the Covid-19 global pandemic on various aspects of corporate governance in the future. This is because the Covid-19 global pandemic is not only a health crisis, and it has been found to affect various firms' aspects and performance, including their governance structure (Khatib and Nour, 2021).

[Insert Figure 1 here]

\subsection{Journal outlets}

Table II shows that the literature sample of Malaysian corporate governance are distributed across fifty-eight different journals, where the following are the top three leading journals: Asian Review of Accounting (15 articles), Managerial Auditing Journal (13 articles), and Corporate Governance: The International Journal of Business in Society (11 articles). The fragmented nature of this area of research is evidenced by 41 different outlets, in which each journal has published only one paper related to the concepts of interest.

The impact of the field is reflected by the number of citations. Twenty-seven articles have received more than fifty citations each. The most cited papers are Haniffa and Cooke (2002, 739 citations), Mitton (2002, 658 citations), Haniffa and Cooke (2005, 649 citations), Haniffa and Hudaib (2006, 365 citations), Rahman and Ali (2006, 247 citations), Mak and Kusnadi (2005, 222 citations), Deesomsak et al. (2004, 213 citations), Said et al. (2009, 166 citations), Ghazali and Weetman (2006, 142 citations), and Abdullah (2004, 122 citations). Among the earliest research, Haniffa and Cooke (2002) used archival data to evaluate the 
determinants of voluntary information disclosure among non-financial listed companies in Malaysia.

[Insert Table II here]

\subsection{Research methods}

The research methods of the previous studies were divided into four types: non-empirical, review, qualitative, and quantitative. As shown in Table III, more than $90 \%$ of the selected literature are quantitative and only two were review papers identified in our sample. These papers focused on corporate governance differences between Islamic and conventional banking (Alnasser and Muhammed, 2012), and one offered a review of the improvements of CG in Malaysian via the introduction of new laws (Rachagan and Kuppusamy, 2013). This finding confirms our previous argument about the lack of comprehensive review research on various facets of Malaysian CG, despite the increase of empirical studies in recent years. Furthermore, one non-empirical study was identified in the literature sample conducted by Muniandy and Ali (2012), which discusses the environmental factors that influence the development of accounting standards, suggesting that the improvement of CG standards had a major influence on the financial reporting practices in Malaysia. There were 118 quantitative empirical research papers; the vast majority (115 papers) of these studies were conducted using archival data, and only three articles utilized primary data (i.e., Johl et al., 2013; Mazlina and Ahmad, 2011; Ramdani and Witteloostuijn, 2010).

Only four qualitative research articles were found. Semi-structured interviews were conducted by Liew (2007) to evaluate the perspectives of leading players in Malaysia's corporate governance development. Zain and Subramaniam (2007) focused on internal auditors' perceptions and their interactions with audit committee members in Malaysia. Hassan and Christopher (2005) studied the role of religion in the disclosure of CG in the Malaysian banking sector. The qualitative research was taken a step further by Magalhães and Al-Saad (2013), who employed a cross-country sample from Malaysia, UAE, Bahrain, and Kuwait to evaluate the roles of monitoring mechanisms in safeguarding the interests of unrestricted investment account holders as major stakeholders in the Islamic financial institutions. There is a distinct absence of mixed-method studies and meta-analyses in Malaysia. The findings also suggest that there are insufficient studies using qualitative or mixed-method research that cover the Malaysian context, despite these methods being 
recommended by several researchers (Adinehzadeh et al., 2018; Esa and Ghazali, 2012; Haniffa and Hudaib, 2006; Yatim, 2010).

\section{[Insert Table III here]}

\subsection{Theories}

A theoretical framework provides an appropriate theoretical base for positing a relationship between two or more constructs. Table III shows that researchers have been interested in new theoretical perspectives in recent years, such as stakeholder theory, critical mass theory, and upper echelon theory. We found that the most frequently used theoretical perspective is agency theory ( 82 documents), followed by resource dependency theory (13 documents), stewardship theory (13 documents) and signalling theory ( 9 documents). This finding is in line with several previous studies (Cuomo et al., 2016; Gonzales-Bustos and Hernández-Lara, 2016; Khatib et al., 2020a; Li et al., 2020), which confirm the importance of these theoretical perspectives in explaining governance roles. In total, 24 studies did not explicitly apply a theoretical foundation. 27 different theories were explicitly applied in the sample literature, while 15 theories had been employed only once and four theories appeared twice, such as critical mass theory (Abdullah, 2014; Abdullah and Ismail, 2016) and upper echelon theory (Alazzani et al., 2017; Ismail and Manaf, 2016).

\subsubsection{Agency theory}

Agency theory is the most common theoretical framework in the sample literature, having been applied in 82 studies. This theory suggests that the conflict of interests between executives and owners has brought about certain problems, such as information asymmetry and agency conflicts. Despite the fact that agency theory is often associated with the principal and agent conflict of interests, the literature applied the agency perspective to explore topics such as firm performance (Bhatt and Bhatt, 2017), earning management (Johari et al., 2009), disclosure quality (Haji and Ghazali, 2013a; Mgammal et al., 2018), financial policy (Deesomsak et al., 2004; Yusof and Ismail, 2016), and corporate social responsibility (Ahmad et al., 2017; Sundarasen et al., 2016). However, it has been suggested that this theory helps explain the monitoring role of governance mechanisms, while the policy setting and advisory role can be better understood by utilizing multiple theories (Filatotchev and Boyd, 2009; Li et al., 2020). 


\subsubsection{Resource dependency theory}

Resource dependency theory was applied in 23 studies; it suggests that firms secure scarce resources by increasing the quality of the governance structure, including improvements to both financial and human resources. Governance mechanisms provide an essential channel to connect firms with an external business environment, which is one important factor behind corporate effectiveness (Pfeffer, 1972). The theory forms a theoretical foundation for the role of board members in providing resources and advice (Saad et al., 2020). The literature applied this theory to explore topics such as firm performance (Low et al., 2015), intellectual capital (Haji and Ghazali, 2013b), risk-taking (Ng et al., 2013), earning management (AlRassas and Kamardin, 2016), and disclosure quality (Zainon et al., 2014).

\subsubsection{Stewardship theory}

Stewardship theory emphasizes the individualistic behaviour of firms' agents. In contrast to an agency perspective, the stewardship theory suggests that there are similar interests among shareholders, directors, and executives (Donaldson and Davis, 1991). Therefore, executives tend to act in the best interest of all stakeholders, given they are motivated in their role by the intrinsic reward they receive (Kallamu and Saat, 2015). Based on the foundation of this theory, Rahman and Ali (2006) suggested that firm performance is enhanced by CEO duality, since their compensations are tied to firm performance, and the same argument was reported by several other studies (e.g., Goh et al., 2014; Haniffa and Cooke, 2002). Meanwhile, Low et al. (2015) used this foundation to address the importance of female executives in enhancing firm performance.

\subsubsection{Other theories}

Other theoretical perspectives have been rarely used. For example, stakeholder theory, which mainly discusses structures of CG that are designed in a way that represents all stakeholders, is discussed in six studies (Yasser et al., 2017; Mgammal et al., 2018), while signalling theory was applied in nine studies (e.g., Mgammal et al., 2018; Rashid et al., 2012). Signalling theory suggests that firms disclose information as signals about their current position in terms of governance, capital structure, ownership, social, and environmental information. Furthermore, to investigate the association between the firm and society in terms of a social contract, six studies applied legitimacy theory (Basiruddin and Ahmed, 2019; Haniffa and Cooke, 2005; Low et al., 2015). In recent years, researchers have shown interest in using 
critical mass and upper echelon theories to explain the importance of gender diversity of boards (Abdullah, 2014; Alazzani et al., 2017; Ismail and Manaf, 2016; Low et al., 2015). It should be noted that a limited number of studies applied cultural and behavioural theories. For example, integrating cultural or behavioural theories into multiple theoretical perspectives might help to develop our understanding and subsequently help us better explain the diverse functions of various corporate governance aspects. Indeed, these aspects have been frequently suggested for future work (i.e., Haniffa and Cooke, 2005; Low et al., 2015; Rahmat et al., 2009; Said et al., 2018).

\subsection{Data geography}

In this study, given that we focus on the Malaysian context, it was not surprising that 106 articles were based on evidence from the Malaysian market. The rest of the empirical research papers were based on multi-country data (17 papers). Among them, five studies focused on Malaysia and Singapore markets (Bradbury et al., 2006; Kusnadi, 2011; Lai and Samers, 2017; Mak and Kusnadi, 2005). Basiruddin and Ahmed (2019) utilized data from Malaysia and Indonesia. These studies showed that the impact of governance on organizational outcomes is different among various countries. For instance, Mak and Kusnadi (2005) reported that ownership concentration is significantly related to firm value in Malaysia, but not in Singapore. Yet, both countries are highly ranked in terms of external shareholder protection (Kusnadi, 2011). Similarly, Jiang and Peng (2011) utilized data from as many as eight economies and found empirical evidence that ownership structure impacts firm performance depending on the countries under examination.

It should be noted that researchers have largely concentrated on comparing the Malaysian market to other emerging markets especially Singapore, Indonesia, Thailand, Philippines, Hong Kong (e.g., Deesomsak et al., 2004; Grassa and Matoussi, 2014; Magalhães and Al-Saad, 2013; Mitton, 2002; Ooi et al., 2015). However, there is no research in Malaysia using cross-countries data other than surrounding markets, such as the Middle East, Latin America, and African countries (Adinehzadeh et al., 2018; Husnin et al., 2016; Jaafar et al., 2014; Rashid et al., 2012; Sulaiman et al., 2015). Such studies could help to understand the role of culture and business environment dimensions. 


\subsection{Modelling}

In our literature sample, qualitative studies used samples that include a maximum of sixteen observations (Magalhães and Al-Saad, 2013) or at least three firms (Hassan and Christopher, 2005). On the other hand, quantitative archival studies utilized data from at least fourteen firms (Wasiuzzaman and Gunasegavan, 2013) or at most 1527 observations (Deesomsak et al., 2004). Moreover, empirical studies utilized more than three regression models on average and tested about five hypotheses, with more than five explanatory variables (see Table IV). Although firm performance is the most examine topic related to corporate governance in Malaysia, researchers used on average three independent variables. This highlights the need for more comprehensive studies that include several corporate governance attributes rather than only focusing on the conventional mechanisms. According to Brown et al. (2011), corporate governance mechanisms consist of the board of directors' attributes, the audit committee and ownership structure. Three independent variables, on average, indicate that there is a lack of comprehensive studies that integrate all governance attributes.

Moreover, only three studies used mediating variables (e.g., Haat et al., 2008; Adinehzadeh et al., 2018), while nineteen studies used moderating variables (Ali et al., 2008; Goh et al., 2014). Most of the research articles that included moderators or mediators concentrated on firm performance and earnings management. Haat et al. (2008) provided empirical evidence that the transparency policy of corporations plays a significant role in mediating the governance and performance association. Additionally, several regression methods have been applied in the sample literature, such as structural equations modelling, hierarchical, ordinary least square, logistics regression, partial least square, two stages least square, and generalized method of moments (GMM). The structural equation model was employed in four studies (Janggu et al., 2014; Said et al., 2018; Tam and Tan, 2007). Our findings suggest that the strength of the structural equation model technique has not been fully exploited by the literature. It has been suggested that this technique helps us examine several constructs in a single model. This advantage could help scholars build and explore more complex models like CG.

Furthermore, the GMM estimation technique is considered an efficient estimator, since it creates the first difference of all variables to address the endogeneity issue, which is well documented in the governance literature. Interestingly, only four studies applied GMM estimation in the sample literature (Al-Jaifi et al., 2017; Che-Ahmad et al., 2020; Kallamu 
and Saat, 2015). GMM estimation controls unobservable heterogeneity, simultaneity, and the influence of past performance on the present firm's decisions (Che-Ahmad et al., 2020). Despite the fact that some researchers confirm non-linearity, there is a lack of work that considers the non-linear impact of CG attributes (Ooi et al., 2015; Chong et al., 2018).

Regarding data collection, the vast majority of the empirical studies utilized archived data. Only five out of 118 quantitative studies investigated corporate governance aspects in Malaysia using primary data (questionnaire) (Johl et al., 2013; Ramdani and Witteloostuijn, 2010; Rashid and Ibrahim, 2002). Mazlina and Ahmad (2011) studied the relationship between managerial ownership and agency costs by using both secondary and primary data (questionnaire). Similarly, Haniffa and Cooke (2005) used a semi-structured questionnaire to verify the results of the regression analysis regarding the impact of $\mathrm{CG}$ and culture on corporate social reporting. The use of primary data (questionnaires and interviews) may provide richer data on corporate governance research as it enables researchers to collect more observations, which are unavailable in the annual reports. The present investigation, however, showed that there is a lack of survey research on Malaysian CG (Esa and Ghazali, 2012; Nyambia and Hamdan, 2018; Yusof and Ismail, 2016).

\section{[Insert Table IV here]}

\subsection{Research questions}

Following Li et al. (2020), we categorized the questions addressed in each research article as follows: discussion of general issues, descriptive research, relationships between corporate governance characteristics, outcomes of CG, and antecedents of CG. However, we could not provide a comprehensive evaluation of these categories because about $95 \%$ of our sample literature discussed the outcomes of corporate governance and only seven research articles took a different direction. Germain et al. (2014) investigated the determinants of boardroom size and independence in the Malaysian market, while, Abdullah (2014) limited their study to the determinant of board gender diversity, and Jaafar et al. (2014) studied the disclosure of directors' remunerations. These studies have found that firm characteristics, such as size and age, are significant determinants of its governance structure. There are no studies so far that have been found to consider the factors that determine the characteristics of other important governance attributes, such as audit committee, risk committee, remuneration committee, board meeting, financial experts, among others. In France, Jeanjean and Stolowy (2009) found evidence that growth opportunities significantly determine the financial expertise of 
the boardroom. Similarly, Greco (2011) reported that board and audit committee meetings of Italian firms are determined by the characteristics of firms and boardrooms.

Furthermore, other scholars addressed general issues related to corporate governance in Malaysia, including Liew (2007), who addressed the factors behind the recent developments of the Malaysian corporate governance system, and Lai and Samers (2017), who focused on the governance of Islamic banks in Singapore and Malaysia. Similarly, Grassa and Matoussi (2014) evaluated the CG practices of Islamic banks in seven countries suggesting that there is a significant difference between them. Lastly, Zain and Subramaniam (2007) provided insights into the interactions between the internal audit perception and the audit committee. Overall, we found that corporate governance-related research in the Malaysian context focuses only on the outcomes (discussed in the next section), neglecting other categories such as the antecedent of governance mechanisms and the interaction between them.

\subsection{Corporate governance outcomes}

In this section, we summarize the outcomes of CG studied in our sample literature. We categorised research outcomes into seven groups: firm performance, earnings management, disclosure quality, auditing quality, corporate social responsibility, remunerations, and other themes. We included a report in each group to determine if it explicitly covers the theme of the group. As shown earlier, Table IV presents a descriptive evaluation of each category.

\subsubsection{Firm performance}

Firm performance is a critical factor that is affected by CG. In the reviewed studies, firm performance has largely been measured by a single indicator, such as Tobin's Q, as a proxy for market return (Ameer et al., 2010; Ghazali, 2010; Kusnadi, 2011; Mak and Kusnadi, 2005), Return on assets (Chong et al., 2018; Ramdani and Witteloostuijn, 2010), and return on equity (Low et al., 2015). Other research utilized a combination of these proxies (Bhatt and Bhatt, 2017; Rahman and Haniffa, 2005; Tam and Tan, 2007). As shown in Table V, some researchers have included other performance indicators, such as earnings before interest and tax (Alias et al., 2017), return on invested capital (Bhatt and Bhatt, 2017), market-to-book ratio (Goh et al., 2014), earnings per share, and profit margin (Abdullah, 2004). The general evidence documented in the literature is in line with agency theory, where well-governed firms perform better compared to poorly governed firms. Yet, some studies have proven otherwise. For instance, Jackling and Johl (2009) reported that no single theory explains the nexus 
between corporate governance and performance. Also, it has been suggested that the governance-performance association depends on the performance indicator employed (Guest, 2009; Mertzanis et al., 2018). Nevertheless, the literature focuses on the financial measurements of firm performance, while research on the non-financial (operational) performance does not exist. As noted by Li et al. (2020), operational performance in terms of growth is a vital outcome of CG.

[Insert Table $\mathrm{V}$ here]

As explained earlier, a significant number of studies on firm performance and CG association yielded mixed results. For example, Ghazali (2010) found weak evidence for the relationship between firm performance and CG quality. Similarly, Wasiuzzaman and Gunasegavan (2013) reported that boardroom characteristics do not exert any impact on bank profitability. Whereas, Bhatt and Bhatt (2017) found evidence that corporate performance is significantly enhanced by the CG rules and practices in Malaysia.

Certain methodological issues might be behind this inconsistency with the empirical findings, such as variables measurement, sample size, period, and endogeneity problems (Chong et al., 2018; Haniffa and Hudaib, 2006). For instance, Ooi et al. (2015) found a nonlinear connection between the diversification of board and firm performance. Similarly, Chong et al. (2018) argued that firm performance can be harmfully influenced by a large board and therefore corporations should have an optimal board size. This nonlinearity has been reported in the literature, and cannot be evaluated by linear regression methods that are used in most of the sample literature. This non-linear or indirect impact of CG on firm performance can be explained by the policy-setting role of the board, wherein the impact of this role on the organizational outcomes could be achieved through policy (Khatib et al., 2021a). This argument is further supported by Tam and Tan (2007) who found a significant mediating role for leverage level on the association between performance and governance attributes.

Moreover, the analysis showed that the majority of prior studies used samples of nonfinancial firms of listed firms without discussing industry differences (e.g., Alias et al., 2017; Low et al., 2015). Haniffa and Hudaib (2006) found evidence that mining and plantation sectors perform poorly in comparison to firms in the industry sector. One study that was conducted by Kallamu and Saat (2015) focused on the financial industry and Goh et al. 
(2014) concentrated on the manufacturing sector. These studies concluded that the correlation between $\mathrm{CG}$ and firm performance might differ between industries.

\subsubsection{Earnings management}

In the sample literature, 15 research papers explored the impact of corporate governance on earnings management and accounting conservatism, which is the second most examined theme related to CG in Malaysian studies. As shown in Table VI, the vast majority of existing studies focused on non-financial companies and little attention has been given to a single industry. Yet, the results of these articles are inconclusive. Rahman and Ali (2006) found that earnings management is insignificantly affected by CG attributes, including audit committee and board independence. Meanwhile, this association was found to be negative by Bradbury et al. (2006), who found that abnormal working capital accruals are reduced by audit committee independence and board size. In contrast, Mohammad et al. (2016) limited their research to manufacturing firms and found that earnings management is positively associated with the effectiveness of the audit committee and the board of directors. These inconclusive findings of prior work might be attributed to the endogeneity issues that are commonly reported in the earning management literature (Johari et al., 2009; Kolsi and Grassa, 2017; Al-Jaifi, 2017). This issue can be driven by the causality between governance variables and earnings management or omitted variables and it is difficult to test for potential endogeneity problems using simple ordinary least square estimation. Yet, all the existing studies have ignored this issue, except Che-Ahmad et al. (2020) who applied the GMM technique to mitigate the biases associated with the static panel.

Furthermore, some scholars took their research a step further by employing the moderating impact of firm characteristics on this association, such as audit committee attributes (Al-Rassas and Kamardin, 2016), family ownership (Abdullah and Ismail, 2016), firm size (Ali et al., 2008), and CEO characteristics (Che-Ahmad et al., 2020). These studies provided empirical evidence that corporate governance variables and some of the firms' characteristics have an interactive influence on earnings management (i.e., Al-Rassas and Kamardin, 2016; Ali et al., 2008). Whereas, Abdullah and Ismail (2016) did not find any support for the interaction between board gender diversity and family ownership in influencing earnings management, indicating that the interaction between governance variables and firm characteristics might not be supported for all factors.

[Insert Table VI here] 


\subsubsection{Disclosure quality}

The association between corporate governance and disclosure quality has received considerable attention from researchers (13 studies). Such studies have dealt with voluntary disclosure (Akhtaruddin and Haron, 2010; Ghazali and Weetman, 2006; Haji and Ghazali, 2013a; Haniffa and Cooke, 2002; Ho and Taylor, 2013; Zainon et al., 2014), tax disclosure (Mgammal et al., 2018), governance disclosure (Hassan and Christopher, 2005; Sulaiman et al., 2015), online disclosure (Hashim et al., 2014), and management commentary disclosure (Said et al., 2018). This interest in the disclosure and governance relationship was triggered by the financial crisis of 1997 in South-East Asia, which resulted in significant environmental change. It was suggested that lack of transparency and accountability in some East Asian corporations may have contributed to the depth of the economic crisis.

Table VII shows that although the general findings of the previous literature argue that good governance structure increases the disclosure quality (Ho and Taylor, 2013) the results on a few governance attributes are mixed. Haji and Ghazali (2013a) found that government ownership is highly significant in explaining the quality of voluntary disclosure. On the other hand, Ghazali and Weetman (2006) reported that voluntary disclosure is not affected by government ownership, while director ownership has a significant impact on the quality of voluntary disclosure.

A study conducted by Akhtaruddin and Haron (2010) included a moderating variable to the model and found that board independence moderates the association between corporate voluntary and board ownership. Additionally, one study in our literature sample looked beyond the individual governance attributes by employing a governance index and suggested that the strength of a firm's corporate governance structure is a potentially important determinant of a firm's disclosure (Ho and Taylor, 2013). Prior studies mainly concentrated on the disclosure quality of non-financial information and studies on a single industry are limited. Also, there is a lack of studies that compare the Malaysian market with another contexts, since all the existing studies were carried out using the Malaysian sample only. Finally, time series and chronological sequence analysis on corporate governance and disclosure quality point to a need for more research that uses panel data in this association.

[Insert Table VII here] 


\subsubsection{Auditing quality}

Following several scandals in the early 2000 s, academic research has been motivated to investigate CG and auditing effectiveness in protecting firms' investments and shareholders' interests (El-Dyasty and Elamer, 2020). Audit effectiveness, as measured by auditing fees, is the most examined theme in this area (AlQadasi and Abidin, 2018; Bliss et al., 2007; Husnin et al., 2013, 2016; Johl et al., 2012; Yatim et al., 2006). Other scholars have evaluated the timeliness of audit reports (Mohamad-Nor et al., 2010; Baatwah et al., 2019), auditor switching (Nasser et al., 2006), auditor ethnicity (Asmuni et al., 2015), and internal auditor perceptions (Zain and Subramaniam, 2007). It has been found that in Malaysia the introduction of Malaysian codes of corporate governance has influenced the effectiveness of audit quality through the restructuring of CG monitoring tools, such as audit committee and internal audit function (Husnin et al., 2013). This correlation, however, varies between sectors. For example, AlQadasi and Abidin (2018) reported that no evidence supports corporate governance demanding a higher quality audit, especially for politically connected firms.

Additionally, we found that some of these studies focused on audit committee characteristics (Yatim et al., 2006; Baatwah et al., 2019; Johl et al., 2012), a combination between audit committee characteristics, ownership and board structure (Mohamad-Nor et al., 2010; Husnin et al., 2013; Husnin et al., 2016), and governance mechanisms, excluding audit committee (AlQadasi and Abidin, 2018; Asmuni et al., 2015; Bliss et al., 2007; Husnin et al., 2016). Moreover, the existing studies were conducted using a sample of non-financial Malaysian firms while there were no single sector or cross-country studies. In Yemen, Hazaea et al. (2020) showed that there is a significant interaction between audit quality and governance attributes in enhancing the performance of banks. Also, some attributes of CG have been overlooked in the audit quality literature, such as (but not limited to) board demographic and cognitive diversity, CEO characteristics, and the cognitive diversity of the audit committee (Yatim et al., 2006; Bliss et al., 2007; Husnin et al., 2013).

\subsubsection{Corporate social responsibility (CSR)}

Firms with a good governance structure can achieve a balance between ethical practice and profitable operation (Elmagrhi et al., 2019; Hassan et al., 2020). In the last five years, due to the importance of achieving this balance, there was a growing interest among researchers to understand the association between corporate governance and CSR (14 studies). Some studies 
were carried out to examine CSR's influence via factors such as board independence (Janggu et al., 2014; Ahmad et al., 2017), board size (Esa and Ghazali, 2012; Said et al., 2013), gender diversity (Alazzani et al., 2017; Yasser et al., 2017), CEO duality (Said et al., 2009; Sundarasen et al., 2016), a different type of ownership (Darus et al., 2013; Haniffa and Cooke, 2005; Ghazali, 2007), director interlock (Wan-Hussin, 2009; Darus et al., 2013), audit committee (Sundarasen et al., 2016), remuneration (Karim, 2021), and board meetings (Haji, 2013). In the meantime, other scholars carried out their research using an overall governance index to evaluate the association (Adinehzadeh et al., 2018; Iatridis, 2013). However, although the consensus was that CG is positively associated with CSR (Adinehzadeh et al., 2018; Iatridis, 2013), the empirical evidence is mixed (see, Wan-Hussin, 2009; Ahmad et al., 2017; Sundarasen et al., 2016).

Ahmad et al. (2017) found evidence that the link between corporate governance and CSR is industry specific. Yet, there has been a lack of studies that deal with a single industry and all existing studies neglected the industry effect. Also, little is known about this association in the financial industry, as all existing research excluded the financial sector from their analysis. Similarly, empirical studies have focused on the Malaysian context only. To understand the role of culture and business environment dimensions, a comparative study between countries would help us understand this association (Adinehzadeh et al., 2018; Haniffa and Cooke, 2005). Despite the inherent limits on the ability of studies based on archived data to capture all dimensions of CSR, all the empirical studies in the literature sample utilized archived data, which point to the need for work involving more detailed interviews, which may help our understanding of these issues (Esa and Ghazali, 2012; Haniffa and Cooke, 2005). Such methods might also help with other media disclosure, such as newspapers, the internet, and in-house magazines, which are mediums that are suggested by some researchers (see, Ahmad et al., 2017; Darus et al., 2013; Haniffa and Cooke, 2005).

\subsubsection{Remunerations}

In today's business environment, board members have a great responsibility to protect the interest of stakeholders. They are responsible for monitoring management activities and enhancing compliance with rules and regulations. They are also accountable for a firm's failure. Due to the growing responsibility of board members, firms have begun to offer competitive remuneration packages to attract expert directors who are capable of enhancing the organizational outcomes. Hence, there is a growing interest in understanding the 
determinants of director remunerations in Malaysia, as evident by the number of prior research. Nahar Abdullah (2006a) found evidence from distressed firms that board independence and the extent of non-executive directors' interests are found to have a negative influence on directors' remuneration. The only study to use time series data was conducted by Lee and Isa (2015), who concentrated on the financial industry and found that directors' remuneration is positively associated with board independence and negatively with board size, while CEO duality is not significant. Nyambia and Hamdan (2018) studied the executive remuneration of small firms and found that there is a significant positive relationship between executive ownership, board size and executive remuneration. However, the findings of the existing studies are inconclusive and vary across industries.

Ahmad et al. (2016) focused on the characteristics of directors such as age, tenure, and qualification, and found that age and tenure of directors are positively related to total remuneration, while directors' qualification exerts an insignificant impact on remuneration. However, the literature regarding corporate governance and remunerations is still unclear and is thus full of opportunities. Future studies could consider remuneration related to stock options, which is a factor that is overlooked by prior studies (Ahmad et al., 2016; Jaafar et al., 2014; Nyambia and Hamdan, 2018). Future research is encouraged to focus on a comparative study using cross country data (Jaafar et al., 2014), using more than one-year dataset (Jaafar et al., 2014; Ahmad et al., 2016), and encourages to deal with governance and ownership mechanisms that have received less attention.

\subsubsection{Other themes}

The extant literature on Malaysian corporate governance documents a variety of alreadyexplored research themes. However, one of the most important decisions within firms is the financing decision. Despite the impact of CG on financial policy being well documented in the literature, only a few research papers evaluated this association in the Malaysian market. Some papers examined the impact of CG on dividend policy (Benjamin, 2015; Yusof and Ismail, 2016), capital structure (Hussain et al., 2018; Mursalim et al., 2017; Suto, 2003; Deesomsak et al., 2004), and agency cost (Mazlina and Ahmad, 2011). Additionally, the connection between CG and intellectual capital was examined in four studies (Ahmed Haji, 2015; Gan et al., 2013; Haji and Ghazali, 2013b; Rashid et al., 2012). Other research papers focused on different themes, such as initial public offerings (Badru et al., 2017; Yatim, 2011), financial distress (Nahar Abdullah, 2006b; Rahmat et al., 2009), risk-taking (Ng et al., 2013), 
investor protection and fraud (Hasnan et al., 2013; Magalhães and Al-Saad, 2013), and investment and market efficiency (Al-Jaifi et al., 2017; Ismail and Manaf, 2016; Nor et al., 2018).

However, it should be noted that, in the Malaysian market, a very limited number of research papers explored the antecedent of CG. Germain et al. (2014) studied the determining factors of boardroom structure in Malaysian firms. Abdullah (2014) examined the factors that determine boardroom diversity in terms of gender, while Yatim (2010) focused on governance determinants of the risk management committee in Malaysian firms.

\subsection{Corporate governance characteristics}

In our sample literature, board composition is the most frequently discussed corporate governance indicator (45 times), followed by board diversity (42 times). Table VIII shows that the literature has focused on the gender diversity of boards, while other diversity indicators have received less attention, such as education, tenure, age, nationality, and experience. This result is in line with other systematic review research (Khatib et al., 2021a; Li et al., 2020).

\section{[Insert Table VIII here]}

Regarding board characteristics, only a few studies have considered the multidirectorship of the board members (Wan-Hussin, 2009; Darus et al., 2013; Hasnan et al., 2013). Similarly, the main focus of the empirical studies was the audit committee, while very limited work has been conducted on the nomination committee, risk management committee, sharia committee, and remuneration committee. Table IX provides a descriptive summary of all governance mechanisms that have been employed in the Malaysian context, including board characteristics, which is the most examined governance aspect, board committees, ownership structure, top management characteristics, and governance indexes.

\section{[Insert Table IX here]}

\section{Discussion and future research agenda}

Malaysia's capital market is characterized by excessive government intervention, high ownership concentration, weak legal systems and enforcement thereof (Al-Rassas and Kamardin, 2016; Aldhamari, et al., 2020). Due to these characteristics, Malaysia experienced a number of challenges during the Asian financial crisis. This has reignited the debate 
regarding the need for effective governance practices. In the case of Malaysia, a series of revised corporate governance codes was introduced to improve corporate governance practices (MCCG, 2000, revised MCCG 2007, and MCCG 2012).

The introduction of the Malaysian code of corporate governance has attracted scholars' attention. A large number of studies followed that evaluated the role of corporate governance in enhancing organizational outcomes and market development within the country. Those studies explored the impact of corporate governance on several organizational aspects (i.e., firm performance, audit quality, and earnings management). It has been found that, in Malaysia, the introduction of the Malaysian code on corporate governance influenced the effectiveness of audit quality and firm performance by restructuring the available CG monitoring tools, such as the audit committee and the internal audit function (Husnin et al., 2013). The existing literature has significantly enhanced our understanding of the vital roles of $\mathrm{CG}$ on organizations and market development. We have subsequently identified several opportunities for future research.

The investigation revealed that there is a growing interest among researchers to explore $\mathrm{CG}$ mostly in relation to firm performance and earnings management. However, despite this significant growth, there is a lack of reviews on the research on Malaysian CG. In terms of research settings and designs, the analysis indicates that there is no research on the impact of CG on CSR, disclosure quality, and audit quality using cross-country data (comparative studies). Hence, to understand the role of cultural differences and business environment dimensions influence between countries, there is a need for more corporate governance research in Malaysia using cross-countries data (Adinehzadeh et al., 2018; Ahmad et al., 2017). Furthermore, the existing literature has mainly focused on non-financial firms and a very limited number of empirical studies (6 papers) have been carried out on a single industry, including the financial sector (Grassa and Matoussi, 2014; Kallamu and Saat, 2015; Lee and Isa, 2015; Ooi et al., 2015). For instance, Ahmad et al. (2017) provided evidence that the connotation between corporate governance and corporate social responsibility is industry specific. Yet, there is a lack of studies on a single industry and all existing research has neglected the industry effect. Moreover, it is well documented in the literature that the characteristics of small-medium enterprises (SMEs) are significantly different from listed firms. Surprisingly, there are no studies on the corporate governance of SMEs. More research around this critical gap is thus encouraged. 
In addition, the sample literature shows a lack of diversity in terms of research design, wherein the majority of prior studies are quantitative and have been carried out using archived data. Only a few studies used survey or interview data. Indeed, the use of primary data (survey or interview) is the most frequent suggestion for future research in reviewed corporate governance research, since it is argued that it would provide important insights into aspects that cannot be captured by secondary data (Adinehzadeh et al., 2018; Gan et al., 2013). Therefore, future work could unpack the black box of CG in Malaysia by carrying out qualitative research to enhance our understanding of various governance aspects in Malaysia.

Furthermore, as illustrated in the CG outcomes section, the vast majority of empirical studies on governance have resulted in inconclusive findings. One reason behind this might be the apparent methodological issues related to statistical tools of panel data analysis, such as unobserved heterogeneity, reverse causality and dynamic endogeneity. Several studies failed to control for these problems. We, therefore, encourage researchers to take advantage of regression methods that address these problems, such as GMM estimation and two-stage least squares, which are rarely used in the sample literature (Al-Jaifi et al., 2017; Che-Ahmad et al., 2020; Kallamu and Saat, 2015).

We also suggest that further work should investigate the non-linear impact of corporate governance, as this factor was evidenced by only a few studies (Kusnadi, 2011; Low et al., 2015; Mak and Kusnadi, 2005; Wahab et al., 2017). For instance, Khatib et al. (2020b) argue that corporate governance might have an indirect association with firm performance and management might use debt to manipulate the governance quality within a firm (over-governance hypothesis). This nonlinearity has been reported in the literature. This factor cannot be evaluated by the linear regression methods that are used the most in the sample literature. Therefore, future research could look beyond the direct association between firm performance and CG, or explore the policy-setting role of the board, where the impact of this role on the organizational outcomes could be achieved through the policy set by the board room (Khatib et al., 2021a). This argument is further supported by Tam and Tan (2007), who found a significant mediating role for leverage level on the association between performance and governance attributes.

Further work could also focus on a single industry to enhance our knowledge on this topic. The majority of prior studies used samples of non-financial firms or listed firms without discussing the industry differences (e.g., Alias et al., 2017; Low et al., 2015). For 
example, Haniffa and Hudaib (2006) found evidence that mining and plantation sectors perform poorly when compared to firms in the industry sector. Moreover, Kallamu and Saat (2015) focused on the financial industry, while Goh et al. (2014) concentrated on the manufacturing sector.

Prior studies have used a variety of CG attributes, such as board characteristics, board committees, ownership structure, top management characteristics, and only a few studies have used governance index to measure the overall governance quality. However, we found that some mechanisms received less attention from researchers. While the extant literature often discusses board diversity, especially in terms of gender, there are critical gaps around the other diversity indicators (demographic and cognitive) and the interactions between them. We note that there is a gap in the literature since most studies address the audit committee characteristics. We thus encourage future researchers to explore nomination, risk management, sharia, and remuneration committees. Additionally, top management characteristics are less frequently studied. Future studies could therefore look at different aspects of leadership, in terms of the board, chair, CEO, or top management. Moreover, it is suggested that researchers should pay more attention to the different levels of ownership structure (see, May et al., 2018), and future studies are encouraged to explore the antecedent of governance mechanisms, since this is a factor that has been almost neglected in the literature.

Lastly, the Covid-19 pandemic has been extremely disruptive with histrionic health-associated effects, such as a high death toll, high patient numbers and global damaging economic effects involving substantial job shortfalls, corporate liquidations, and a worldwide recession (IMF, 2020). Thus, a number of future studies can be conducted in the Malaysian market to investigate the corporate governance implications of the Covid-19 pandemic. For example, studies could ask, how is the control of firms, the role and effectiveness of accountability systems (e.g., managerial compensation, financial information, boards of directors, auditing) impacted? Also, future studies should recognize the financial market consequences of different corporate governance structures. However, such a pandemic increases all types of problems, and consequently these issues require serious investigation, with a view to establish a more complete and clear framework, and subsequently develop sufficient regulations to ensure the sustainability of strong corporate governance systems, both during and after the Covid-19 pandemic. 


\section{Conclusion}

In the last two decades, Malaysia has devoted significant effort to improving corporate governance $(\mathrm{CG})$ codes and practices within the capital market. Also, firms have taken steps to strengthen their governance practices and enhance corporate accountability. This interest was followed by a growing number of studies that deal with the impact of corporate governance on various aspects of corporations in the Malaysian market. However, there is a lack of review research that assesses the empirical studies in this field. We followed a scientific and systematic method to identify the high-quality papers included in the content analysis. Searching Scopus and Web of Science databases, the initial sample hit 1348 articles that explicitly address corporate governance in the Malaysian context, and these studies were then subject to quality assessment. In total, 125 published studies on the corporate governance of Malaysian firms were selected in the final sample.

We found that most research papers addressed the outcomes of certain corporate governance characteristics, while fewer studies addressed the antecedents of corporate governance. Also, the findings of the prior studies on the association between corporate governance and other themes are mixed, pointing to a need for further attention to qualitative research. Our comprehensive literature review thus provides an up-to-date assessment of the research landscape in the field of corporate governance. It covers the Malaysian context and delivers several interesting insights and recommendations for future research. The findings also suggest that resource dependency theory and agency theory are the key theoretical perspectives applied in the sample literature, while a limited number of studies applied cultural and behavioural theories. Exploring the cultural or behavioural theories of corporate governance might also help us develop our understanding in order to better explain the diverse functions of corporate governance aspects. Overall, despite the fact that the existing studies that have contributed significantly to the advancement of our knowledge on corporate governance, there is ample room for future research. Lastly, academic examinations could contribute to forming a richer knowledge of how and why the Covid-19 pandemic could affect corporate governance systems in different areas.

Our study has a number of limitations. First, organizing/grouping the sampled research in line with specific criteria is always tenuous. Relevant knowledge may also come from studies that are not included in the selected list, given this study used criteria based on the time of publication and number of citations of each study that was included in the content 
analysis. Second, studies occasionally fall under various subject areas and categorization can be tricky and at times may be questionable. In future, a more extensive study can be conducted, considering multiple databases along with the Web of Science and Scopus databases, or conducted by comparing Malaysian studies with the literature of different markets. 


\section{References}

Abdullah, M., Evans, L., Fraser, I. and Tsalavoutas, I. (2015), "IFRS mandatory disclosures in Malaysia: the influence of family control and the value (ir)relevance of compliance levels", Accounting Forum, Vol. 39 No. 4, pp. 328-348.

Abdullah, S., Ku Ismail, K.N.I. and Nachum, L. (2014), "Does having women on boards create value? The impact of societal perceptions and corporate governance in emerging markets", Strategic Management Journal, Vol. 37 No. 3, pp. 466-476.

Abdullah, S.N. (2004), "Board composition, CEO duality and performance among Malaysian listed companies", Corporate Governance: The International Journal of Business in Society, Vol. 4 No. 4, pp. 47-61.

Abdullah, S.N. (2014), "The causes of gender diversity in Malaysian large firms", Journal of Management and Governance, Vol. 18 No. 4, pp. 1137-1159.

Abdullah, S.N. and Ismail, K.N.I.K. (2016), "Women directors, family ownership and earnings management in Malaysia", Asian Review of Accounting, Vol. 24 No. 4, pp. 525-550.

Abdullah, S.N., Yusof, N.Z.M. and Nor, M.N.M. (2010), "Financial restatements and corporate governance among Malaysian listed companies", Managerial Auditing Journal, Vol. 25 No. 6, pp. 526-552.

Adinehzadeh, R., Jaffar, R., Abdul Shukor, Z. and Che Abdul Rahman, M.R. (2018), "The mediating role of environmental performance on the relationship between corporate governance mechanisms and environmental disclosure", Asian Academy of Management Journal of Accounting and Finance, Vol. 14 No. 1, pp. 153-183.

Ahmad, N.B.J., Rashid, A. and Gow, J. (2017), "Board independence and corporate social responsibility (CSR) reporting in Malaysia", Australasian Accounting, Business and Finance Journal, Vol. 11 No. 2, pp. 61-85.

Ahmed Haji, A. (2015), "The role of audit committee attributes in intellectual capital disclosures: Evidence from Malaysia", Managerial Auditing Journal, Vol. 30 No. 8-9, pp. 756-784.

Akhtaruddin, M. and Haron, H. (2010), "Board ownership, audit committees' effectiveness and corporate voluntary disclosures", Asian Review of Accounting, Vol. 18 No. 1, pp. 68-82.

Al Amosh, H. and Khatib, S.F.A. (2021), "Ownership structure and environmental, social and governance performance disclosure: the moderating role of the board independence", Journal of Business and Socio-Economic Development, Forthcoming.

Alazzani, A., Hassanein, A. and Aljanadi, Y. (2017), "Impact of gender diversity on social and environmental performance: evidence from Malaysia", Corporate Governance: The International Journal of Business in Society, Vol. 17 No. 2, pp. 266-283.

Aldhamari, R., Mohamad Nor, M.N., Boudiab, M. and Mas'ud, A. (2020), "The impact of political connection and risk committee on corporate financial performance: evidence from financial firms in Malaysia", Corporate Governance: The International Journal of Business in Society, Vol. 20 No. 7, pp. 1281-1305.

Ali, S.M., Mohd Salleh, N. and Hassan, M.S. (2008), "Ownership structure and earnings management in Malaysian listed companies: The size effect", Asian Journal of Business and Accounting, Vol. 1 No. 2, pp. 89-116.

Alias, N., Yaacob, M.H. and Jaffar, N. (2017), "Governance structure, corporate restructuring and performance", Polish Journal of Management Studies, Vol. 15 No. 1, pp. 7-14.

Al-Jaifi, H.A. (2017), "Ownership concentration, earnings management and stock market liquidity: evidence from Malaysia", Corporate Governance: The International Journal of Business in Society, Vol. 17 No. 3, pp. 490-510.

Al-Jaifi, H.A., Al-rassas, A.H. and AL-Qadasi, A.A. (2017), "Corporate governance strength 
and stock market liquidity in Malaysia", International Journal of Managerial Finance, Vol. 13 No. 5, pp. 592-610.

Alnabsha, A., Abdou, H.A., Ntim, C.G. and Elamer, A.A. (2018), "Corporate boards, ownership structures and corporate disclosures : Evidence from a developing country", Journal of Applied Accounting Research, Vol. 19 No. 1, pp. 20-41.

Alnasser, S. (2012), "What has changed? The development of corporate governance in Malaysia", Journal of Risk Finance, Vol. 13 No. 3, pp. 269-276.

Alnasser, S.A.S. and Muhammed, J. (2012), "Introduction to corporate governance from Islamic perspective", Humanomics, Vol. 28 No. 3, pp. 220-231.

AlQadasi, A. and Abidin, S. (2018), "The effectiveness of internal corporate governance and audit quality: the role of ownership concentration - Malaysian evidence", Corporate Governance: The International Journal of Business in Society, Vol. 18 No. 2, pp. 233253.

Al-Rassas, A.H. and Kamardin, H. (2016), "Earnings quality and audit attributes in high concentrated ownership market", Corporate Governance: The International Journal of Business in Society, Vol. 16 No. 2, pp. 377-399.

Alshbili, I., Elamer, A.A. and Beddewela, E. (2019), "Ownership types, corporate governance and corporate social responsibility disclosures", Accounting Research Journal, Vol. 33 No. 1, pp. 148-166.

Ameer, R., Ramli, F. and Zakaria, H. (2010), "A new perspective on board composition and firm performance in an emerging market", Corporate Governance: The International Journal of Business in Society, Vol. 10 No. 5, pp. 647-661.

Annuar, H.A. (2014), "Independent non-executive directors strategic role - some evidence from Malaysia", Corporate Governance: The International Journal of Business in Society, Vol. 14 No. 3, pp. 339-351.

Asmuni, A.I.H., Nawawi, A. and Salin, A.S.A.P. (2015), "Ownership structure and auditor' s ethnicity of Malaysian public listed companies”, Pertanika Journal of Social Sciences \& Humanities, Vol. 23 No. 3, pp. 603-622.

Baatwah, S.R., Salleh, Z. and Stewart, J. (2019), "Audit committee chair accounting expertise and audit report timeliness: The moderating effect of chair characteristics", Asian Review of Accounting, Vol. 27 No. 2, pp. 273-306.

Badru, B.O., Ahmad-Zaluki, N.A. and Wan-Hussin, W.N. (2017), "Board characteristics and the amount of capital raised in the Malaysian IPO market", Journal of Multinational Financial Management, Vol. 42-43 No. 2017, pp. 37-55.

Basiruddin, R. and Ahmed, H. (2019), "Corporate governance and Shariah non-compliant risk in Islamic banks: Evidence from Southeast Asia", Corporate Governance: The International Journal of Business in Society, Vol. 20 No. 2, pp. 240-262.

Benjamin, S.J. (2015), "Corporate governance and dividends payout: Are they substitutes or complementary?", Journal of Asia Business Studies, Vol. 9 No. 2, pp. 177-194.

Bhatt, P.R. and Bhatt, R.R. (2017), "Corporate governance and firm performance in Malaysia", Corporate Governance: The International Journal of Business in Society, Vol. 17 No. 5, pp. 896-912.

Bliss, M.A., Muniandy, B. and Majid, A. (2007), "CEO duality, audit committee effectiveness and audit risks: A study of the Malaysian market", Managerial Auditing Journal, Vol. 22 No. 7, pp. 716-728.

Bradbury, M., Mak, Y.T. and Tan, S.M. (2006), "Board characteristics, audit committee characteristics and abnormal accruals", Pacific Accounting Review, Vol. 18 No. 2, pp. 47-68.

Brown, P., Beekes, W. and Verhoeven, P. (2011), "Corporate governance, accounting and finance: A review", Accounting and Finance, Vol. 51 No. 1, pp. 96-172. 
Bufarwa, I.M., Elamer, A.A., Ntim, C.G. and AlHares, A. (2020), "Gender diversity, corporate governance and financial risk disclosure in the UK", International Journal of Law and Management, Vol. 62 No. 6, pp. 521-538.

Che-Ahmad, A.B., Olarinoye Abdulmalik, S. and Mohamad Yusof, N.Z. (2020), "CEO career horizons and earnings quality in family firms", Asian Review of Accounting, Vol. 28 No. 2, pp. 153-172.

Chong, L.L., Ong, H.B. and Tan, S.H. (2018), "Corporate risk-taking and performance in Malaysia: the effect of board composition, political connections and sustainability practices", Corporate Governance: The International Journal of Business in Society, Vol. 18 No. 4, pp. 635-654.

Cruz-González, C., Rodríguez, C.L. and Segovia, J.D. (2021), "A systematic review of principals' leadership identity from 1993 to 2019", Educational Management Administration and Leadership, Vol. 49 No. 1, pp. 31-53.

Cuomo, F., Mallin, C. and Zattoni, A. (2016), "Corporate governance codes: A review and research agenda", Corporate Governance: An International Review, Vol. 24 No. 3, pp. $222-241$.

Darus, F., Hamzah, E.A.C.K. and Yusoff, H. (2013), "CSR web reporting: the influence of ownership structure and mimetic isomorphism", Procedia Economics and Finance, Vol. 7 No. 2013, pp. 236-242.

Deesomsak, R., Paudyal, K. and Pescetto, G. (2004), "The determinants of capital structure: Evidence from the Asia Pacific region", Journal of Multinational Financial Management, Vol. 14 No. 4-5, pp. 387-405.

Donaldson, L. and Davis, J.H. (1991), "Stewardship theory or agency theory: CEO governance and shareholder returns", Australian Journal of Management, Vol. 16 No. 1, pp. 49-64.

Elamer, A.A., AlHares, A., Ntim, C.G. and Benyazid, I. (2018), "The corporate governancerisk-taking nexus: evidence from insurance companies", International Journal of Ethics and Systems, Vol. 34 No. 4, pp. 493-509.

Elamer, A.A., Ntim, C.G. and Abdou, H.A. (2020), "Islamic Governance, National Governance, and Bank Risk Management and Disclosure in MENA Countries", Business and Society, Vol. 59 No. 5, pp. 914-955.

Elamer, A.A., Ntim, C.G., Abdou, H.A., Owusu, A., Elmagrhi, M. and Ibrahim, A.E.A. (2021), "Are bank risk disclosures informative? Evidence from debt markets", International Journal of Finance \& Economics, Vol. 26 No. 1, pp. 1270-1298.

El-Dyasty, M.M. and Elamer, A.A. (2020), "The effect of auditor type on audit quality in emerging markets: evidence from Egypt", International Journal of Accounting and Information Management, Vol. 29 No. 1, pp. 43-66.

Elmagrhi, M.H., Ntim, C.G., Elamer, A.A. and Zhang, Q. (2019), “A study of environmental policies and regulations, governance structures and environmental performance: The role of female directors.", Business Strategy and the Environment, Vol. 28 No. 1, pp. 206-220.

Endenich, C. and Trapp, R. (2020), "Ethical implications of management accounting and control: a systematic review of the contributions from the Journal of Business Ethics", Journal of Business Ethics, Vol. 163 No. 2, pp. 309-328.

Esa, E. and Ghazali, N.A.M. (2012), "Corporate social responsibility and corporate governance in Malaysian government-linked companies", Corporate Governance: The International Journal of Business in Society, Vol. 12 No. 3, pp. 292-305.

E-Vahdati, S., Zulkifli, N. and Zakaria, Z. (2019), "Corporate governance integration with sustainability: a systematic literature review", Corporate Governance: The International Journal of Business in Society, Vol. 19 No. 2, pp. 255-269. 
Filatotchev, I. and Boyd, B.K. (2009), "Taking stock of corporate governance research while looking to the future: Guest editorial", Corporate Governance: An International Review, Vol. 17 No. 3, pp. 257-265.

Gan, K., Saleh, Z., Abessi, M. and Huang, C.C. (2013), "Intellectual capital disclosure in the context of corporate governance", International Journal of Learning and Intellectual Capital, Vol. 10 No. 1, pp. 52-70.

Germain, L., Galy, N. and Lee, W. (2014), "Corporate governance reform in Malaysia: Board size, independence and monitoring", Journal of Economics and Business, Vol. 75 No. 2014, pp. 126-162.

Ghazali, N.A.M. (2010), "Ownership structure, corporate governance and corporate performance in Malaysia", International Journal of Commerce and Management, Vol. 20 No. 2, pp. 109-119.

Ghazali, N.A.M. and Weetman, P. (2006), "Perpetuating traditional influences: Voluntary disclosure in Malaysia following the economic crisis", Journal of International Accounting, Auditing and Taxation, Vol. 15 No. 2, pp. 226-248.

Goh, C.F., Rasli, A. and Khan, S.U.R. (2014), "CEO duality, board independence, corporate governance and firm performance in family firms: Evidence from the manufacturing industry in Malaysia", Asian Business and Management, Vol. 13 No. 4, pp. 333-357.

Gonzales-Bustos, J.P. and Hernández-Lara, A.B. (2016), "Corporate governance and innovation: A systematic literature review", Corporate Ownership and Control, Vol. 13 No. 3, pp. 33-45.

Grassa, R. and Matoussi, H. (2014), "Corporate governance of Islamic banks: A comparative study between GCC and Southeast Asia countries", International Journal of Islamic and Middle Eastern Finance and Management, Vol. 7 No. 3, pp. 346-362.

Greco, G. (2011), "Determinants of board and audit committee meeting frequency", Managerial Auditing Journal, Vol. 26 No. 3, pp. 208-229.

Guest, P.M. (2009), "The impact of board size on firm performance: Evidence from the UK", European Journal of Finance, Vol. 15 No. 4, pp. 385-404.

Haat, M.H.C., Rahman, R.A. and Mahenthiran, S. (2008), "Corporate governance, transparency and performance of Malaysian companies", Managerial Auditing Journal, Vol. 23 No. 8, pp. 744-778.

Haji, A.A. (2013), "Corporate social responsibility disclosures over time: Evidence from Malaysia", Managerial Auditing Journal, Vol. 28 No. 7, pp. 647-676.

Haji, A.A. and Ghazali, N.A.M. (2013a), "The quality and determinants of voluntary disclosures in annual reports of Shari'ah compliant companies in Malaysia", Humanomics, Vol. 29 No. 1, pp. 24-42.

Haji, A.A. and Ghazali, N.A.M. (2013b), "A longitudinal examination of intellectual capital disclosures and corporate governance attributes in Malaysia", Asian Review of Accounting, Vol. 21 No. 1, pp. 27-52.

Haniffa, R. and Hudaib, M. (2006), "Corporate governance structure and performance of Malaysian listed companies", Journal of Business Finance and Accounting, Vol. 33 No. 7-8, pp. 1034-1062.

Haniffa, R.M. and Cooke, T.E. (2002), "Culture, corporate governance and disclosure in Malaysian corporations", Abacus, Vol. 38 No. 3, pp. 317-349.

Haniffa, R.M. and Cooke, T.E. (2005), "The impact of culture and governance on corporate social reporting", Journal of Accounting and Public Policy, Vol. 24 No. 5, pp. 391-430.

Hashim, M.H., Nawawi, A. and Salin, A.S.A.P. (2014), "Determinants of strategic information disclosure-Malaysian evidence", Corporate Governance: The International Journal of Business in Society, Vol. 15 No. 3, pp. 547-572.

Hasnan, S., Abdul Rahman, R. and Mahenthiran, S. (2013), "Management motive, weak 
governance, earnings management, and fraudulent financial reporting: Malaysian evidence", Journal of International Accounting Research, Vol. 12 No. 1, pp. 1-27.

Hassan, A., Elamer, A.A., Fletcher, M. and Sobhan, N. (2020), "Voluntary assurance of sustainability reporting: evidence from an emerging economy", Accounting Research Journal, Vol. 33 No. 2, pp. 391-410.

Hassan, S. and Christopher, T. (2005), "Corporate governance statement disclosure of Malaysian banks and the role of Islam", Asian Review of Accounting, Vol. 13 No. 2, pp. 36-50.

Hazaea, S.A., Tabash, M.I., Khatib, S.F.A., Zhu, J. and Al-kuhali, A.A. (2020), "The Impact of Internal Audit Quality on Financial Performance of Yemeni Commercial Banks: An Empirical Investigation", The Journal of Asian Finance, Economics and Business, Vol. 7 No. 11, pp. 867-875.

Hazaea, S.A., Tabash, M.I., Zhu, J., Khatib, S.F.A. and Farhan, N.H.S. (2021a), "Internal audit and financial performance of Yemeni commercial banks: Empirical evidence", Banks and Bank Systems, Vol. 16 No. 2, pp. 137-147.

Hazaea, S.A., Zhu, J., Al-Matari, E.M., Senan, N.A.M., Khatib, S.F.A. and Ullah, S. (2021b), "Mapping of internal audit research in China: A systematic literature review and future research agenda", Cogent Business \& Management, Vol. 8 No. 1, pp 1-23.

Ho, P.L. and Taylor, G. (2013), "Corporate governance and different types of voluntary disclosure: Evidence from Malaysian listed firms", Pacific Accounting Review, Vol. 25 No. 1, pp. 4-29.

Husnin, A.I., Nawawi, A. and Puteh Salin, A.S.A. (2016), "Corporate governance and auditor quality-Malaysian evidence”, Asian Review of Accounting, Vol. 24 No. 2, pp. 202-230.

Husnin, A.I., Nawawi, A. and Salin, A.S.A.P. (2013), "Corporate governance structure and its relationship with audit fee-evidence from Malaysian public listed companies", Asian Social Science, Vol. 9 No. 15, pp. 305-317.

Hussain, H.I., Abidin, I.S.Z., Ali, A. and Kamarudin, F. (2018), "Debt maturity and family related directors: Evidence from a developing market", Polish Journal of Management Studies, Vol. 18 No. 2, pp. 118-134.

Iatridis, G.E. (2013), "Environmental disclosure quality: Evidence on environmental performance, corporate governance and value relevance", Emerging Markets Review, Vol. 14 No. 1, pp. 55-75.

Ismail, K.N.I.K. and Manaf, K.B.A. (2016), "Market reactions to the appointment of women to the boards of Malaysian firms", Journal of Multinational Financial Management, Vol. 36 No. 2016, pp. 75-88.

Jaafar, M.Y., Nawawi, A. and Salin, A.S.A.P. (2014), "Directors' remuneration disclosure and firm characteristics - Malaysian evidence", International Journal of Economics and Management, Vol. 8 No. 2, pp. 269-293.

Jackling, B. and Johl, S. (2009), "Board structure and firm performance: Evidence from India's top companies", Corporate Governance: An International Review, Vol. 17 No. 4, pp. 492-509.

Janggu, T., Darus, F., Zain, M.M. and Sawani, Y. (2014), "Does good corporate governance lead to better sustainability reporting? an analysis using structural equation modeling", Procedia -Social and Behavioral Sciences, Vol. 145 No. 2014, pp. 138-145.

Jeanjean, T. and Stolowy, H. (2009), "Determinants of board members' financial expertise Empirical evidence from France", The International Journal of Accounting, Vol. 44 No. 4, pp. 378-402.

Jiang, Y. and Peng, M.W. (2011), "Are family ownership and control in large firms good, bad, or irrelevant?", Asia Pacific Journal of Management, Vol. 28 No. 1, pp. 15-39.

Johari, N.H., Saleh, N.M., Jaffar, R. and Hassan, M.S. (2009), "The influence of board 
independence, competency and ownership on earnings management in Malaysia", International Journal of Economics and Management, Vol. 2 No. 2, pp. 281-306.

Johl, S., Subramaniam, N. and Mat Zain, M. (2012), "Audit Committee and CEO ethnicity and audit fees: Some Malaysian evidence", International Journal of Accounting, Vol. 47 No. 3, pp. 302-332.

Johl, S.K., Kaur Johl, S., Subramaniam, N. and Cooper, B. (2013), "Internal audit function, board quality and financial reporting quality: Evidence from Malaysia", Managerial Auditing Journal, Vol. 28 No. 9, pp. 780-814.

Kallamu, B.S. and Saat, N.A.M. (2015), "Audit committee attributes and firm performance: Evidence from Malaysian finance companies", Asian Review of Accounting, Vol. 23 No. 3, pp. 206-231.

Karim, S. (2021), "An investigation into the remuneration-CSR nexus and if it can be affected by board gender diversity", Corporate Governance: The International Journal of Business in Society, Vol. 21 No. 4, pp. 608-625.

Khatib, S.F.A. and Nour, A.-N.I. (2021), "The impact of corporate governance on firm performance during The COVID-19 pandemic: Evidence from Malaysia", Journal of Asian Finance, Economics and Business, Vol. 8 No. 2, pp. 0943-0952.

Khatib, S.F.A., Abdullah, D.F., Elamer, A.A. and Abueid, R. (2021a), "Nudging toward diversity in the boardroom: A systematic literature review of board diversity of financial institutions", Business Strategy and the Environment, Vol. 30 No. 2, pp. 985-1002.

Khatib, S.F.A., Abdullah, D.F., Hendrawaty, E. and Elamer, A.A. (2021b), "A bibliometric analysis of cash holdings literature: current status, development, and agenda for future research", Management Review Quarterly, Forthcoming.

Khatib, S.F.A., Abdullah, D.F., Hendrawaty, E. and Yahaya, I.S. (2020a), "Corporate governance mechanisms and capital structure", Journal of Critical Reviews, Vol. 7 No. 16, pp. 463-471.

Khatib, S.F.A., Abdullah, D.F., Kabara, A.S., Hazaea, S.A. and Rajoo, T.S. (2020b), "Does debts have any impact on governance bundle and agency costs? over-governance hypothesis", Technium Social Sciences Journal, Vol. 9 No. 1, pp. 384-396.

Kim, P., Rasiah, D. and Tasnim, R. (2012), "A review of corporate governance: ownership structure of domestic-owned banks in term of government connected ownership, and foreign ownership of commercial banks in Malaysia", The Journal of Organizational Management Studies, Vol. 1 No. 2012, pp. 1-18.

Kolsi, M.C. and Grassa, R. (2017), "Did corporate governance mechanisms affect earnings management? Further evidence from GCC Islamic banks", International Journal of Islamic and Middle Eastern Finance and Management, Vol. 10 No. 1, pp. 2-23.

Kusnadi, Y. (2011), "Do corporate governance mechanisms matter for cash holdings and firm value?", Pacific Basin Finance Journal, Vol. 19 No. 5, pp. 554-570.

Lai, K.P.Y. and Samers, M. (2017), "Conceptualizing Islamic banking and finance: a comparison of its development and governance in Malaysia and Singapore", Pacific Review, Vol. 30 No. 3, pp. 405-424.

Lee, S.P. and Isa, M. (2015), "Directors' remuneration, governance and performance: the case of Malaysian banks", Managerial Finance, Vol. 41 No. 1, pp. 26-44.

Li, H., Terjesen, S. and Umans, T. (2020), Corporate governance in entrepreneurial firms: A systematic review and research agenda, Small Business Economics, Vol. 54 No. 1, pp.43-74.

Liew, P.K. (2007), "Corporate governance reforms in Malaysia: The key leading players' perspectives", Corporate Governance: An International Review, Vol. 15 No. 5, pp. 724 740.

Linnenluecke, M.K., Marrone, M. and Singh, A.K. (2020), "Conducting systematic literature 
reviews and bibliometric analyses", Australian Journal of Management, Vol. 45 No. 2, pp. 175-194.

Low, D.C.M., Roberts, H. and Whiting, R.H. (2015), "Board gender diversity and firm performance: Empirical evidence from Hong Kong, South Korea, Malaysia and Singapore", Pacific Basin Finance Journal, Vol. 35 No. 2015, pp. 381-401.

Magalhães, R. and Al-Saad, S. (2013), "Corporate governance in Islamic financial institutions: The issues surrounding unrestricted investment account holders", Corporate Governance: The International Journal of Business in Society, Vol. 13 No. 1, pp. 39-57.

Mak, Y.T. and Kusnadi, Y. (2005), "Size really matters: Further evidence on the negative relationship between board size and firm value", Pacific Basin Finance Journal, Vol. 13 No. 3, pp. 301-318.

May, T.Y., Fah, C.F. and Hassan, T. (2018), "Impacts of ownership concentration and liquidity on stock momentum profitability in Malaysia", Asian Academy of Management Journal of Accounting and Finance, Vol. 14 No. 1, pp. 57-81.

Mazlina, M. and Ahmad, A.C. (2011), "Agency theory and managerial ownership: evidence from Malaysia”, Managerial Auditing Journal, Vol. 26 No. 5, pp. 419-436.

MCCG (2007), The Malaysian Code on Corporate Governance, Securities Commission Malaysia, Kuala Lumpur, available at: https://www.sc.com.my/regulation/corporategovernance.

MCCG (2017), The Malaysian Code on Corporate Governance, Securities Commission Malaysia, Kuala Lumpur, available at: https://www.sc.com.my/regulation/corporategovernance.

Mertzanis, C., Basuony, M.A.K. and Mohamed, E.K.A. (2018), "Social institutions, corporate governance and firm-performance in the MENA region", Research in International Business and Finance, Vol. 48, pp. 75-96.

Mgammal, M.H., Bardai, B. and Ku Ismail, K.N.I. (2018), "Corporate governance and tax disclosure phenomenon in the Malaysian listed companies", Corporate Governance: The International Journal of Business in Society, Vol. 18 No. 5, pp. 779-808.

Mitton, T. (2002), "A cross-firm analysis of the impact of corporate governance on the East Asian financial crisis", Journal of Financial Economics, Vol. 64 No. 2, pp. 215-241.

Mohamad-Nor, M.N., Shafie, R. and Wan-Hussin, W.N. (2010), "Corporate governance and audit report lag in Malaysia", Asian Academy of Management Journal of Accounting and Finance, Vol. 6 No. 2, pp. 57-84.

Mohammad, W.M.W., Wasiuzzaman, S. and Salleh, N.M.Z.N. (2016), "Board and audit committee effectiveness, ethnic diversification and earnings management: a study of the Malaysian manufacturing sector", Corporate Governance: The International Journal of Business in Society, Vol. 16 No. 4, pp. 726-746.

Muniandy, B. and Ali, M.J. (2012), "Development of financial reporting environment in Malaysia", Research in Accounting Regulation, Vol. 24 No. 2, pp. 115-125.

Mursalim, Mallisa, M. and Kusuma, H. (2017), "Capital structure determinants and firms' performance: empirical evidence from Thailand, Indonesia and Malaysia", Polish Journal of Management Studies, Vol. 16 No. 1, pp. 154-164.

Nahar Abdullah, S. (2006a), "Directors' remuneration, firm's performance and corporate governance in Malaysia among distressed companies", Corporate Governance: The International Journal of Business in Society, Vol. 6 No. 2, pp. 162-174.

Nahar Abdullah, S. (2006b), "Board structure and ownership in Malaysia: the case of distressed listed companies", Corporate Governance: The International Journal of Business in Society, Vol. 6 No. 5, pp. 582-594.

Nasser, A.T.A., Wahid, E.A., Nazri, S.N.F.S.M. and Hudaib, M. (2006), "Auditor-client relationship: The case of audit tenure and auditor switching in Malaysia", Managerial 
Auditing Journal, Vol. 21 No. 7, pp. 724-737.

Ng, S.H., Teh, B.H., Ong, T.S. and Soh, W.N. (2014), "A review on family-controlled business groups with particular reference to corporate governance in Malaysia", International Business Management. Vol. 8 No. 5, pp. 268-276.

Ng, T.-H., Chong, L.-L. and Ismail, H. (2013), "Is the risk management only a procedural?", Journal of Risk FinanceFinance, Vol. 14 No. 1, pp. 71-86.

Nielsen, S. (2010), "Top management team diversity: A review of theories and methodologies", International Journal of Management Reviews, Vol. 12 No. 3, pp. 301316.

Nor, N.H.M., Nawawi, A. and Puteh Salin, A.S.A. (2018), "The impact of audit committee independence and auditor choice on firms' investment level", Pertanika Journal of Social Sciences and Humanities, Vol. 26 No. 3, pp. 1433-1454.

Nyambia, H.S. and Hamdan, H. (2018), "The scantness of the effect of corporate governance mechanisms on executive directors' remuneration in small listed companies: evidence from Malaysia", Social Responsibility Journal, Vol. 14 No. 4, pp. 934-949.

Ooi, C.A., Hooy, C.W. and Mat Som, A.P. (2015), "Diversity in human and social capital: Empirical evidence from Asian tourism firms in corporate board composition", Tourism Management, Vol. 48 No. 2015, pp. 139-153.

Pedrini, M. and Ferri, L.M. (2019), "Stakeholder management: a systematic literature review", Corporate Governance: The International Journal of Business in Society, Vol. 19 No. 1, pp. 44-59.

Pfeffer, J. (1972), "Size and composition of corporate boards of directors: The organization and its environment", Administrative Science Quarterly, Vol. 17 No. 2, pp. 218-228.

Rachagan, S. and Kuppusamy, K. (2013), "Encouraging whistle blowing to improve corporate governance? A Malaysian initiative", Journal of Business Ethics, Vol. 115 No. 2, pp. 367-382.

Rahim, M.F.A., Johari, R.J. and Takril, N.F. (2015), "Revisited note on corporate governance and quality of audit committee: Malaysian perspective", Procedia Economics and Finance, Vol. 28 No. 2015, pp. 213-221.

Rahman, R.A. and Ali, F.H.M. (2006), "Board, audit committee, culture and earnings management: Malaysian evidence", Managerial Auditing Journal, Vol. 21 No. 7, pp. 783-804.

Rahman, R.A. and Haniffa, R.M. (2005), "The effect of role duality on corporate performance in Malaysia", Corporate Ownership and Control, Vol. 2 No. 2, pp. 40-47.

Rahmat, M.M., Iskandar, T.M. and Saleh, N.M. (2009), "Audit committee characteristics in financially distressed and non-distressed companies", Managerial Auditing Journal, Vol. 24 No. 7, pp. 624-638.

Ramdani, D. and Witteloostuijn, A. van. (2010), "The impact of board independence and CEO duality on firm performance: A quantile regression analysis for Indonesia, Malaysia, South Korea and Thailand", British Journal of Management, Vol. 21 No. 3, pp. 607-627.

Rasel, M.A. and Win, S. (2020), "Microfinance governance: a systematic review and future research directions", Journal of Economic Studies, Vol. 47 No. 7, pp. 1811-1847.

Rashid, A.A., Ibrahim, M.K., Othman, R. and See, K.F. (2012), "IC disclosures in IPO prospectuses: Evidence from Malaysia”, Journal of Intellectual Capital, Vol. 13 No. 1, pp. 57-80.

Rashid, M.Z.A. and Ibrahim, S. (2002), "Executive and management attitudes towards corporate social responsibility in Malaysia", Corporate Governance: The International Journal of Business in Society, Vol. 2 No. 4, pp. 10-16.

Saad, N.M., Haniff, M.N. and Ali, N. (2020), "Corporate governance mechanisms with 
conventional bonds and Sukuk' yield spreads", Pacific-Basin Finance Journal, Vol. 62 No. 101116, pp. 1-24.

Said, R., Omar, N. and Abdullah, W.N. (2013), "Empirical investigations on boards, business characteristics, human capital and environmental reporting", Social Responsibility Journal, Vol. 9 No. 4, pp. 534-553.

Said, R., Rahim, A.A.A. and Hassan, R. (2018), "Exploring the effects of corporate governance and human governance on management commentary disclosure", Social Responsibility Journal, Vol. 14 No. 4, pp. 843-858.

Said, R., Zainuddin, Y. and Haron, H. (2009), "The relationship between corporate social responsibility disclosure and corporate governance characteristics in Malaysian public listed companies", Social Responsibility Journal, Vol. 5 No. 2, pp. 212-226.

Schiehll, E. and Martins, H.C. (2016), "Cross-national governance research: a systematic review and assessment", Corporate Governance: An International Review, Vol. 24 No. 3, pp. 181-199.

Shariff, N.M., Abidin, A.Z. and Bahar, M.R. (2018), "Developing a framework of corporate governance best practice for the Malaysian tourism small and medium-sized enterprises", GeoJournal of Tourism and Geosites, Vol. 22 No. 1, p. 447.

Shleifer, A. and Vishny, R.W. (1997), "A survey of corporate governance, The Journal of Finance, Vol. 1 No. 2, pp. 737-783.

Sulaiman, M., Majid, N.A. and Arifin, N.M. (2015), "Corporate governance of Islamic financial institutions in Malaysia", Asian Journal of Business and Accounting, Vol. 8 No. 1, pp. 65-93.

Sundarasen, S.D.D., Je-Yen, T. and Rajangam, N. (2016), "Board composition and corporate social responsibility in an emerging market", Corporate Governance: The International Journal of Business in Society, Vol. 16 No. 1, pp. 35-53.

Suto, M. (2003), "Capital structure and investment behaviour of Malaysian firms in the 1990s: a study of corporate governance before the crisis", Corporate Governance: An International Review, Vol. 11 No. 1, pp. 25-39.

Tam, O.K. and Tan, M.G.S. (2007), "Ownership, governance and firm performance in Malaysia”, Corporate Governance: An International Review, Vol. 15 No. 2, pp. 208222.

Tenzer, H., Terjesen, S. and Harzing, A.W. (2017), "Language in international business: a review and agenda for future research", Management International Review, Vol. 57 No. 6, pp. 815-854.

Wahab, E.A.A., Ariff, A.M., Marzuki, M.M. and Sanusi, Z.M. (2017), "Political connections, corporate governance, and tax aggressiveness in Malaysia", Asian Review of Accounting, Vol. 25 No. 3, pp. 424-451.

Walker, K. (2010), "A systematic review of the corporate reputation literature: Definition, measurement, and theory", Corporate Reputation Review, Vol. 12 No. 4, pp. 357-387.

Wan Sulaiman, W.N.A. and Mustafa, S.E. (2020), "Usability Elements in Digital Textbook Development: A Systematic Review”, Publishing Research Quarterly, Vol. 36 No. 1, pp. 74-101.

Wan-Hussin, W.N. (2009), "The impact of family-firm structure and board composition on corporate transparency: Evidence based on segment disclosures in Malaysia", International Journal of Accounting, Vol. 44 No. 4, pp. 313-333.

Wasiuzzaman, S. and Gunasegavan, U.N. (2013), "Comparative study of the performance of Islamic and conventional banks: The case of Malaysia", Humanomics, Vol. 29 No. 1, pp. 43-60.

Yasser, Q.R. and Al Mamun, A. (2016), "The relationship between board leadership structure and earnings management in Asia-Pacific", Accounting Research Journal, Vol. 29 No. 
4, pp. 413-428.

Yasser, Q.R., Al Mamun, A. and Ahmed, I. (2017), "Corporate social responsibility and gender diversity: Insights from Asia Pacific", Corporate Social Responsibility and Environmental Management, Vol. 24 No. 3, pp. 210-221.

Yatim, P. (2010), "Board structures and the establishment of a risk management committee by Malaysian listed firms", Journal of Management and Governance, Vol. 14 No. 1, pp. $17-36$.

Yatim, P. (2011), "Underpricing and board structures: An investigation of Malaysian initial public offerings (IPOs)", Asian Academy of Management Journal of Accounting and Finance, Vol. 7 No. 1, pp. 73-93.

Yatim, P., Kent, P. and Clarkson, P. (2006), "Governance structures, ethnicity, and audit fees of Malaysian listed firms", Managerial Auditing Journal, Vol. 21 No. 7, pp. 757-782.

Yunos, R.M., Ismail, Z. and Smith, M. (2012), "Ethnicity and accounting conservatism: Malaysian evidence", Asian Review of Accounting, Vol. 20 No. 1, pp. 34-57.

Yusof, Y. and Ismail, S. (2016), "Determinants of dividend policy of public listed companies in Malaysia", Review of International Business and Strategy, Vol. 26 No. 1, pp. 88-99.

Zain, M.M. and Subramaniam, N. (2007), "Internal auditor perceptions on audit committee interactions: A qualitative study in Malaysian public corporations", Corporate Governance: An International Review, Vol. 15 No. 5, pp. 894-908.

Zainon, S., Atan, R. and Wah, Y.B. (2014), "An empirical study on the determinants of information disclosure of Malaysian non-profit organizations", Asian Review of Accounting, Vol. 22 No. 1, pp. 35-55.

Zamil, I.A., Ramakrishnan, S., Jamal, N.M., Hatif, M.A. and Khatib, S.F.A. (2021), "Drivers of corporate voluntary disclosure: a systematic review", Journal of Financial Reporting and Accounting, Forthcoming. 


\section{List of figures}

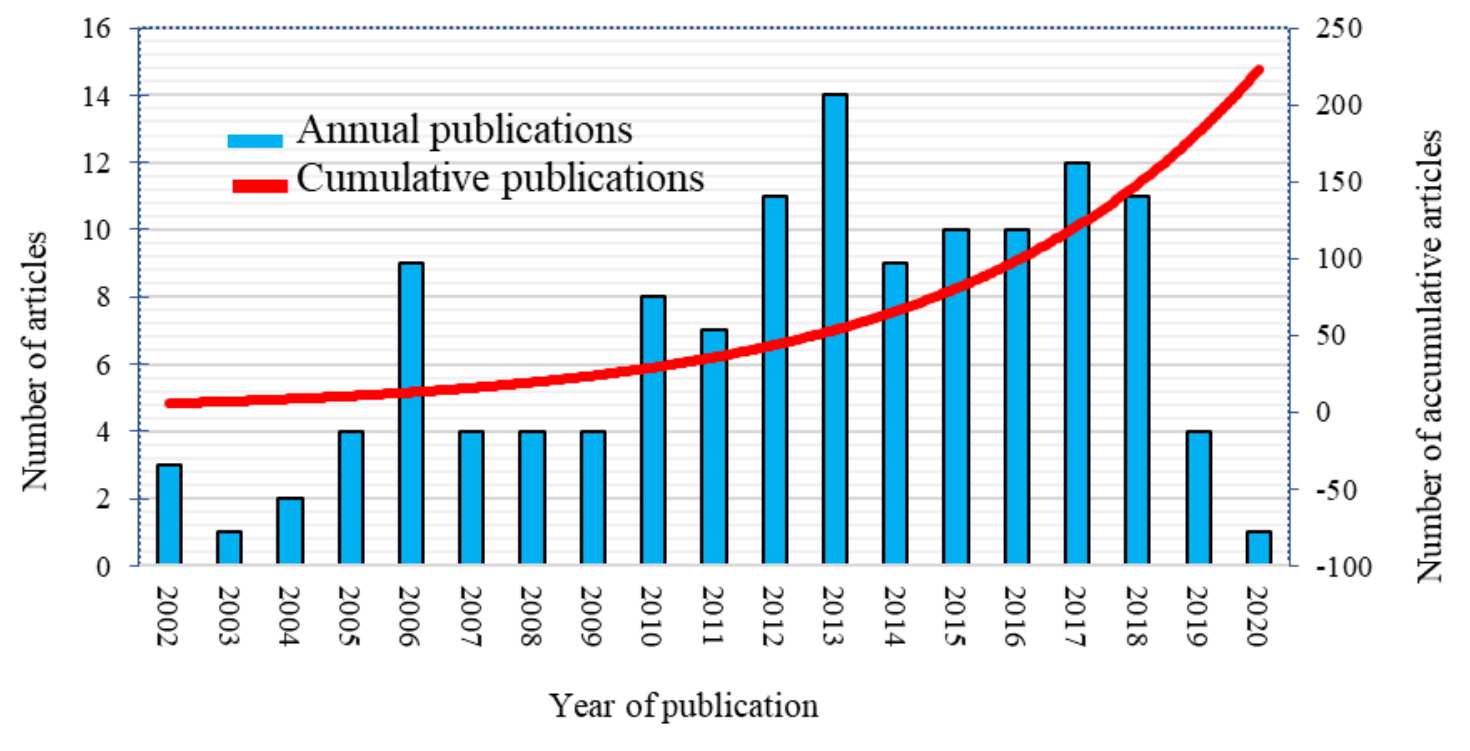

Figure 1: Number of publications per year 


\section{Tables}

Table I: The leading journals publishing quality articles (2008-2017)

\begin{tabular}{lll}
\hline Journal name & \# Papers & Per cent \\
\hline Asian Review of Accounting & 11 & 21.2 \\
Corporate Governance: The International Journal of Business in & & \\
Society & 7 & 34.6 \\
Managerial Auditing Journal & 8 & 50.0 \\
Social Responsibility Journal & 2 & 53.8 \\
Asian Journal of Business and Accounting & 3 & 59.6 \\
Asian Academy of Management Journal of Accounting and Finance & 2 & 63.5 \\
Humanomics & 3 & 69.2 \\
International Journal of Accounting & 2 & 73.1 \\
International Journal of Business and Society & 2 & 76.9 \\
International Journal of Economics and Management & 2 & 80.8 \\
Journal of Management and Governance & 2 & 84.6 \\
Journal of Multinational Financial Management & 2 & 88.5 \\
Pacific Basin Finance Journal & 2 & 92.3 \\
Pertanika Journal of Social Science and Humanities & 2 & 96.2 \\
Polish Journal of Management Studies & 2 & 100.0 \\
\hline
\end{tabular}


Table II: The most influential journals

\begin{tabular}{lll}
\hline Journal name & $\#$ & $\#$ \\
& Papers & Citations \\
\hline Asian Review of Accounting & 15 & 287 \\
Managerial Auditing Journal & 13 & 794 \\
Corporate Governance: The International Journal of Business in & & \\
Society & 11 & 379 \\
Corporate Governance: An International Review & 7 & 441 \\
Pacific Basin Finance Journal & 5 & 356 \\
Social Responsibility Journal & 4 & 235 \\
Asian Academy of Management Journal of Accounting and & & \\
Finance & 4 & 64 \\
Journal of Multinational Financial Management & 3 & 240 \\
International Journal of Accounting & 3 & 129 \\
Asian Journal of Business and Accounting & 3 & 82 \\
Humanomics & 3 & 71 \\
Polish Journal of Management Studies & 3 & 49 \\
\hline
\end{tabular}


Table III: Methodologies and theories across time

\begin{tabular}{llllll}
\hline Methods & $\begin{array}{l}\text { pre- } \\
\text { 2004 }\end{array}$ & $\begin{array}{l}\mathbf{2 0 0 5}- \\
\mathbf{2 0 0 9}\end{array}$ & $\begin{array}{l}\mathbf{2 0 1 0}- \\
\mathbf{2 0 1 4}\end{array}$ & $\begin{array}{l}\mathbf{2 0 1 5}- \\
\mathbf{2 0 2 0}\end{array}$ & Total \\
\hline Research methods & 5 & 22 & 44 & 47 & 118 \\
Quantitative & & 3 & 1 & & 4 \\
Qualitative & & & 2 & & 2 \\
Review & & & 1 & & 1 \\
Non-empirical & 5 & 25 & 48 & 47 & 125 \\
Total & & & & & \\
\hline Theories & 4 & 16 & 26 & 36 & 82 \\
Agency theory & 1 & 3 & 6 & 13 & 23 \\
Resource dependency theory & 1 & 4 & 4 & 4 & 13 \\
Stewardship theory & 1 & 1 & 3 & 4 & 9 \\
Signalling theory & & & 2 & 4 & 6 \\
Stakeholder theory & & 2 & 2 & 2 & 6 \\
Legitimacy theory & & & 5 & 1 & 6 \\
Institutional theory & 1 & 2 & & 1 & 4 \\
Hegemony theory & & & 1 & 1 & 2 \\
Critical mass theory & & & & 2 & 2 \\
Upper echelon theory & 1 & & & 1 & 2 \\
Pecking order theory & 1 & & & 1 & 2 \\
Trade-off theory & 4 & 4 & 2 & 5 & 15 \\
Other theories & 1 & 6 & 14 & 3 & 24 \\
Papers without theory &
\end{tabular}

Other theories including culture theory, human capital theory, socio-emotional wealth theory, career horizon perspective, market timing theory, free cash flow theory, accountability theory, contingency theory, supply-side theory, behavioural theory, spirituality at work theory, social contracting theory, environmental determinism theory, bank control theory, and decision usefulness theory. 
Table IV: Analysis of modelling for quantitative empirical research Content

\begin{tabular}{|c|c|c|c|c|c|c|c|}
\hline $\begin{array}{l}\text { Construct } \\
\text { under study }\end{array}$ & $\begin{array}{l}\text { No. } \\
\text { papers }\end{array}$ & $\begin{array}{l}\text { No. } \\
\text { moderato }\end{array}$ & $\begin{array}{l}\text { No. } \\
\text { rmediator }\end{array}$ & $\begin{array}{l}\text { Avg. No. } \\
\text { regression } \\
\text { models }\end{array}$ & $\begin{array}{l}\text { Avg. No. } \\
\text { explanatory } \\
\text { variables }\end{array}$ & $\begin{array}{l}\text { Avg. } \\
\text { No. } \\
\text { sample }\end{array}$ & $\begin{array}{l}\text { Avg. No. } \\
\text { hypothesis }\end{array}$ \\
\hline $\begin{array}{l}\text { Firm } \\
\text { performance }\end{array}$ & 29 & 9 & 2 & 4.18 & 3.19 & 575.35 & 5.12 \\
\hline $\begin{array}{l}\text { Earnings } \\
\text { managements }\end{array}$ & 16 & 5 & 0 & 3.47 & 5.27 & 326.53 & 6.07 \\
\hline $\begin{array}{l}\text { Disclosure } \\
\text { quality }\end{array}$ & 13 & 2 & 0 & 2.39 & 5.39 & 204.10 & 5.64 \\
\hline Audit quality & 12 & 3 & 0 & 2.64 & 4.91 & 383.67 & 5.45 \\
\hline $\begin{array}{l}\text { Corporate social } \\
\text { responsibility }\end{array}$ & 14 & 0 & 1 & 3.17 & 4.79 & 214.29 & 5.36 \\
\hline Financial policy & 6 & 0 & 0 & 4.00 & 4.00 & 530.33 & 4.40 \\
\hline Remuneration & 5 & 0 & 0 & 2.20 & 5.20 & 345.60 & 5.20 \\
\hline Other themes & 27 & 0 & 0 & 2.90 & 5.91 & 244.77 & 4.95 \\
\hline Overall & 122 & 19 & 3 & 3.12 & 4.83 & 353.10 & 5.27 \\
\hline
\end{tabular}


Table V: Sample of studies on firm performance and corporate governance

\begin{tabular}{|c|c|c|c|}
\hline Authors & Proxy & Method & Findings summary \\
\hline $\begin{array}{l}\text { Rahman } \\
\text { and Haniffa } \\
(2005)\end{array}$ & $\begin{array}{l}\text { Tobin's Q } \\
\text { ROE } \\
\text { ROA }\end{array}$ & $\begin{array}{l}347 \text { non- } \\
\text { financial firms } \\
1996-2000 \\
\text { OLS regression }\end{array}$ & $\begin{array}{l}\text { Firms with CEO duality perform less than their } \\
\text { counterparts with separate leadership of the } \\
\text { board. }\end{array}$ \\
\hline $\begin{array}{l}\text { Abdullah } \\
\text { and Ismail } \\
(2013)\end{array}$ & $\begin{array}{l}\text { ROA } \\
\text { Tobin's Q }\end{array}$ & $\begin{array}{l}100 \text { non- } \\
\text { financial firms } \\
2007 \\
\text { multiple } \\
\text { regression } \\
\end{array}$ & $\begin{array}{l}\text { There is a lack of gender diversity of boards in } \\
\text { Malaysian firms. Ethnic diversity enhances } \\
\text { performance while diverse-board in terms of } \\
\text { gender exerts a negative influence on firm } \\
\text { performance. }\end{array}$ \\
\hline $\begin{array}{l}\text { Abdullah et } \\
\text { al. (2014) }\end{array}$ & $\begin{array}{l}\text { ROA } \\
\text { Tobin's q }\end{array}$ & $\begin{array}{l}841 \text { non- } \\
\text { financial firms } \\
2008 \\
\text { OLS regression }\end{array}$ & $\begin{array}{l}\text { The effect of gender diversity depending on the } \\
\text { performance measurements and varies across } \\
\text { firms' ownership. }\end{array}$ \\
\hline $\begin{array}{l}\text { Alias et al. } \\
(2017)\end{array}$ & EBIT & $\begin{array}{l}136 \text { non- } \\
\text { financial firms } \\
2004-2013 \\
\text { OLS regression }\end{array}$ & $\begin{array}{l}\text { Firm performance is greater in firms with large } \\
\text { size of boards or institutional ownership } \\
\text { because of diversification knowledge, } \\
\text { experience, skills, and strategy. }\end{array}$ \\
\hline $\begin{array}{l}\text { Ameer et al. } \\
(2010)\end{array}$ & Tobin's Q & $\begin{array}{l}277 \text { non- } \\
\text { financial firms } \\
2002 \text { to } 2007\end{array}$ & $\begin{array}{l}\text { There is poor performance in firms with a } \\
\text { substantial number of affiliated non-executive } \\
\text { board members or insider executives. }\end{array}$ \\
\hline $\begin{array}{l}\text { Ghazali } \\
\text { (2010) }\end{array}$ & Tobin's Q & $\begin{array}{l}87 \text { non-financial } \\
\text { firms } \\
2001 \\
\text { multiple } \\
\text { regression }\end{array}$ & $\begin{array}{l}\text { CG does not influence the performance of } \\
\text { Malaysian corporations. }\end{array}$ \\
\hline $\begin{array}{l}\text { Haniffa and } \\
\text { Hudaib } \\
(2006)\end{array}$ & $\begin{array}{l}\text { ROA } \\
\text { Tobin's Q }\end{array}$ & $\begin{array}{l}347 \text { non- } \\
\text { financial firms } \\
1996-2000 \\
\text { OLS regression }\end{array}$ & $\begin{array}{l}\text { Firm performance is significantly influenced by } \\
\text { board size and ownership concentration. The } \\
\text { impact of multiple directorships, CEO duality, } \\
\text { and managerial shareholdings depends on } \\
\text { performance indicators. }\end{array}$ \\
\hline $\begin{array}{l}\text { Jiang and } \\
\text { Peng (2011) }\end{array}$ & $\begin{array}{l}\text { Stock } \\
\text { return }\end{array}$ & $\begin{array}{l}744 \text { family firms } \\
1996 \\
\text { OLS regression }\end{array}$ & $\begin{array}{l}\text { In internal governance structures is } \\
\text { significantly influenced by shareholder } \\
\text { protection and it explains positive or negative } \\
\text { impact on performance in different markets. }\end{array}$ \\
\hline $\begin{array}{l}\text { Low et al. } \\
(2015)\end{array}$ & $\mathrm{ROE}$ & $\begin{array}{l}\text { listed firms } \\
6952 \\
\text { observations } \\
2012-2013 \\
\text { OLS and 2SLS }\end{array}$ & $\begin{array}{l}\text { In markets with greater economic } \\
\text { empowerment and participation of women, the } \\
\text { positive impact of gender diversity appears to } \\
\text { be diminished. }\end{array}$ \\
\hline $\begin{array}{l}\text { Abdullah } \\
(2004)\end{array}$ & $\begin{array}{l}\text { ROE, } \\
\text { ROA } \\
\text { EPS, } \\
\text { Profit } \\
\text { margin } \\
\end{array}$ & $\begin{array}{l}321 \text { non- } \\
\text { financial firms } \\
1994-1996 \\
\text { T-test }\end{array}$ & $\begin{array}{l}\text { Board independence and CEO duality either } \\
\text { individually or jointly do not correlate with } \\
\text { firm performance. }\end{array}$ \\
\hline $\begin{array}{l}\text { Chong et al. } \\
(2018)\end{array}$ & ROA & $\begin{array}{l}21 \text { listed firms } \\
2010-2014 \\
\text { multiple }\end{array}$ & $\begin{array}{l}\text { Firm performance can be harmfully influenced } \\
\text { by a large board and therefore it is better for } \\
\text { corporations to have an optimal board size. }\end{array}$ \\
\hline
\end{tabular}




\begin{tabular}{|l|l|l|l|}
\hline & & regression & \\
\hline $\begin{array}{l}\text { Mak and } \\
\text { Kusnadi } \\
(2005)\end{array}$ & Tobin's Q & $\begin{array}{l}460 \text { listed firms } \\
1999-2000 \\
\text { OLS regression }\end{array}$ & $\begin{array}{l}\text { Firm value is inversely affected by board size. } \\
\text { Overall, there is a weak association between } \\
\text { Tobin's Q and most governance indicators. }\end{array}$ \\
\hline
\end{tabular}


Table VI: Sample of studies on earnings management and corporate governance

\begin{tabular}{|c|c|c|}
\hline Authors & Sample size & Findings summary \\
\hline $\begin{array}{l}\text { Johari et } \\
\text { al. (2009) }\end{array}$ & $\begin{array}{l}224 \text { non-financial } \\
\text { firms } \\
2002-2003 \\
\text { OLS regression }\end{array}$ & $\begin{array}{l}\text { The practice of earning management does not influence } \\
\text { by the CEO duality. Managers are induced to manage } \\
\text { earnings with managerial ownership over } 25 \% \text {. }\end{array}$ \\
\hline $\begin{array}{l}\text { Rahman } \\
\text { and Ali } \\
(2006)\end{array}$ & $\begin{array}{l}97 \text { non-financial } \\
\text { firms } \\
2002-2003 \\
\text { Multiple regression }\end{array}$ & $\begin{array}{l}\text { Larger board size exerts a positive impact on earnings } \\
\text { management while ethnic diversity is not associated } \\
\text { with mitigating earnings management. }\end{array}$ \\
\hline $\begin{array}{l}\text { Al-Rassas } \\
\text { and } \\
\text { Kamardin } \\
(2016)\end{array}$ & $\begin{array}{l}508 \text { non-financial } \\
\text { firms } \\
2009-2012 \\
\text { OLS regression }\end{array}$ & $\begin{array}{l}\text { There is a positive impact between the big four audit } \\
\text { firms, audit committee independence, and investment in } \\
\text { internal audit function on earnings management quality. }\end{array}$ \\
\hline $\begin{array}{l}\text { Abdullah } \\
\text { and Ismail } \\
(2016)\end{array}$ & $\begin{array}{l}603 \text { non-financial } \\
\text { firms } \\
2008-2011 \\
\text { multiple regression }\end{array}$ & $\begin{array}{l}\text { Earnings management is not affected by either the } \\
\text { gender diversity of the audit committee or family } \\
\text { ownership. The latter does not weaken the correlation } \\
\text { between earnings management and the audit committee. }\end{array}$ \\
\hline $\begin{array}{l}\text { Hashim } \\
\text { and Devi } \\
(2008)\end{array}$ & $\begin{array}{l}167 \\
\text { non-financial firms } \\
2004 \\
\text { multiple regression }\end{array}$ & $\begin{array}{l}\text { Neither CEO duality nor board independence is } \\
\text { significant in explaining the level of accrual } \\
\text { manipulations. }\end{array}$ \\
\hline $\begin{array}{l}\text { Mohamma } \\
\text { d et al. } \\
(2016)\end{array}$ & $\begin{array}{l}201 \\
\text { manufacturing } \\
\text { firms } \\
2004-2009 \\
\text { multiple and } \\
\text { logistic regression }\end{array}$ & $\begin{array}{l}\text { Pre- and post-Revised MCCG (2007), the effectiveness } \\
\text { of audit committees and boardroom as well as the ethnic } \\
\text { diversity of a boardroom is positively associated with } \\
\text { earnings management. }\end{array}$ \\
\hline $\begin{array}{l}\text { Che- } \\
\text { Ahmad et } \\
\text { al. }(2020)\end{array}$ & $\begin{array}{l}190 \text { family firms } \\
2005-2016 \\
\text { GMM }\end{array}$ & $\begin{array}{l}\text { The relationship between earnings quality and CEO } \\
\text { career horizon is moderated by the CEO with financial } \\
\text { expertise and family-affiliated CEO. }\end{array}$ \\
\hline $\begin{array}{l}\text { Hashim } \\
\text { and Devi } \\
(2008)\end{array}$ & $\begin{array}{l}280 \text { non-financial } \\
\text { firms } \\
\text { 1999-2005 } \\
\text { multiple regression }\end{array}$ & $\begin{array}{l}\text { Earnings quality is higher in firms with a long-tenured } \\
\text { director, family directors, and substantial shareholdings } \\
\text { by outside directors. In contrast, the quality of reported } \\
\text { earnings is significantly constrained by family } \\
\text { ownership and board ownership. While earnings quality } \\
\text { is not affected by board independence. }\end{array}$ \\
\hline
\end{tabular}


Table VII: Sample of studies on corporate governance and disclosure quality

\begin{tabular}{|c|c|c|}
\hline Authors & Sample size & Findings summary \\
\hline $\begin{array}{l}\text { Haniffa and } \\
\text { Cooke } \\
(2002)\end{array}$ & $\begin{array}{l}167 \text { non-financial } \\
\text { firms } \\
1995 \\
\text { Multiple regression }\end{array}$ & $\begin{array}{l}\text { The extent of voluntary disclosure is inversely } \\
\text { correlated with the chairperson as a non-executive } \\
\text { director. While the ethnic diversity of the board } \\
\text { exerts a significant impact on voluntary disclosure. }\end{array}$ \\
\hline $\begin{array}{l}\text { Ho and } \\
\text { Taylor } \\
(2013)\end{array}$ & $\begin{array}{l}100 \text { non-financial } \\
\text { firms } \\
1996,2001 \text { and } 2006 \\
\text { OLS regression }\end{array}$ & $\begin{array}{l}\text { Corporates tend to disclose more corporate and } \\
\text { strategic information pre and post-crisis. Directors } \\
\text { and senior management information increases in } \\
\text { post-Asian financial crisis periods. This confirms the } \\
\text { importance of corporate governance in determining a } \\
\text { firm's disclosure. }\end{array}$ \\
\hline $\begin{array}{l}\text { Ghazali and } \\
\text { Weetman } \\
(2006)\end{array}$ & $\begin{array}{l}100 \text { non-financial } \\
\text { firms } \\
2001 \\
\text { Stepwise regression }\end{array}$ & $\begin{array}{l}\text { Government ownership does not affect voluntary } \\
\text { disclosure. While the levels of voluntary disclosure } \\
\text { are significantly associated with director ownership. }\end{array}$ \\
\hline $\begin{array}{l}\text { Akhtaruddin } \\
\text { and Haron } \\
(2010)\end{array}$ & $\begin{array}{l}124 \text { non-financial } \\
\text { firms } \\
2003 \\
\text { Hierarchical } \\
\text { regression }\end{array}$ & $\begin{array}{l}\text { Board ownership reduces the extent of voluntary } \\
\text { disclosures. This correlation is weaker for firms with } \\
\text { higher audit committee independence. }\end{array}$ \\
\hline $\begin{array}{l}\text { Sulaiman et } \\
\text { al. }(2015)\end{array}$ & $\begin{array}{l}16 \text { financial firms } \\
2009 \\
\text { Mann-Whitney test }\end{array}$ & $\begin{array}{l}\text { Islamic financial institutions are not particularly } \\
\text { motivated to disclose specific-governance related } \\
\text { information. }\end{array}$ \\
\hline $\begin{array}{l}\text { Hassan and } \\
\text { Christopher } \\
(2005)\end{array}$ & $\begin{array}{l}3 \text { conventional and } \\
\text { Islamic banks } \\
2003 \\
\text { Interview }\end{array}$ & $\begin{array}{l}\text { Having more Malays/Muslim directors or being an } \\
\text { Islamic institution is not associated with higher } \\
\text { disclosure or better governance practices compared } \\
\text { to their counterparts. }\end{array}$ \\
\hline $\begin{array}{l}\text { Abdullah et } \\
\text { al. }(2010)\end{array}$ & $\begin{array}{l}914 \text { non-financial } \\
\text { firms } \\
2002-2005 \\
\text { Logistic regression }\end{array}$ & $\begin{array}{l}\text { The likelihood of financial restatement is not related } \\
\text { to managerial ownership, CEO duality, nomination } \\
\text { committee independence, or board independence. } \\
\text { While it is significantly influenced by outside block } \\
\text { holders. }\end{array}$ \\
\hline $\begin{array}{l}\text { Abdullah et } \\
\text { al. (2015) }\end{array}$ & $\begin{array}{l}451 \text { non-financial } \\
\text { firms } \\
2008 \\
\text { OLS regression }\end{array}$ & $\begin{array}{l}\text { Family control is related negatively to disclosure and } \\
\text { that compliance levels are not valued relevant. }\end{array}$ \\
\hline $\begin{array}{l}\text { Zainon et } \\
\text { al. (2014) }\end{array}$ & $\begin{array}{l}101 \text { non-profit } \\
\text { organizations } \\
2009 \\
\text { Hierarchical } \\
\text { regression }\end{array}$ & $\begin{array}{l}\text { Non-profit institutions with better financial standing } \\
\text { and that receive funding or with external auditors } \\
\text { promote better reporting practice and disclose more } \\
\text { information. }\end{array}$ \\
\hline $\begin{array}{l}\text { Said et al. } \\
(2018)\end{array}$ & $\begin{array}{l}150 \text { non-financial } \\
\text { firms } \\
2014 \\
\text { Structural equation } \\
\text { modelling }\end{array}$ & $\begin{array}{l}\text { The level of information management commentary } \\
\text { disclosed is positively associated with the board } \\
\text { independence and size. Most of the information } \\
\text { disclosure by Malaysian firms was not presented } \\
\text { fully and they are more focused on describing the } \\
\text { process. }\end{array}$ \\
\hline $\begin{array}{l}\text { Mgammal } \\
\text { et al. }(2018)\end{array}$ & $\begin{array}{l}286 \text { non-financial } \\
\text { firms }\end{array}$ & $\begin{array}{l}\text { The managerial ownership and incentive } \\
\text { compensation do not significantly influence tax }\end{array}$ \\
\hline
\end{tabular}




\begin{tabular}{|l|l|l|}
\hline & $\begin{array}{l}2010-2012 \\
\text { OLS regression }\end{array}$ & disclosure. \\
\hline $\begin{array}{l}\text { Haji and } \\
\text { Ghazali }\end{array}$ & $\begin{array}{l}\text { 76 Sharia-compliant } \\
\text { firms }\end{array}$ & $\begin{array}{l}\text { The results indicate that the quality of voluntary } \\
\text { disclosures by sharia-compliant firms is overall low. } \\
\text { The board size and government ownership are } \\
\text { significant in explaining the quality of voluntary } \\
\text { disclosure. }\end{array}$ \\
\hline
\end{tabular}


Table VII: The measurements of board diversity in the Malaysian governance literature

\begin{tabular}{lll}
\hline Item & \# Studies & Example of papers \\
\hline Gender diversity & 18 & Alazzani et al. (2017), and Darus et al. (2013) \\
Ethnic diversity & 10 & Abdullah and Ismail (2013), and Badru et al. (2017) \\
Education diversity & 5 & Ahmad et al. (2016), and Haniffa and Cooke (2002) \\
Religion & 2 & Hassan and Christopher (2005), and Saad et al. (2020) \\
Experience & 3 & Janggu et al. (2014), and Johari et al. (2009) \\
Nationality & 2 & Ameer et al. (2010), and Janggu et al. (2014) \\
Board tenure & 2 & Ahmad et al. (2016), and Hashim and Devi (2008) \\
Age & 2 & Ahmad et al. (2016), and Grassa and Matoussi (2014) \\
\hline
\end{tabular}


Table IX: The number of studies for each governance attributed in Malaysia

\begin{tabular}{|l|l|l|l|l|l|}
\hline Boardroom & Papers & Top management & Papers & $\begin{array}{l}\text { Ownership } \\
\text { structure }\end{array}$ & Papers \\
\hline Size & 31 & CEO duality & 32 & Concentration & 24 \\
\hline Composition & 45 & Chairman ethnic & 1 & Managerial & 12 \\
\hline Meetings & 7 & $\begin{array}{l}\text { Chairman cross- } \\
\text { directorship }\end{array}$ & 2 & Institutional & 10 \\
\hline Diversity & 32 & $\begin{array}{l}\text { Family chairman } \\
\text { /CEO }\end{array}$ & 2 & Government & 10 \\
\hline Family directors & 7 & CEO/ Chairman age & 2 & Family & 9 \\
\hline $\begin{array}{l}\text { Interlock } \\
\text { Board }\end{array}$ & 3 & CEO founder & 1 & Director & 16 \\
\hline Audit & 23 & $\begin{array}{l}\text { CEO tenure } \\
\text { background }\end{array}$ & 1 & Foreign & 10 \\
\hline $\begin{array}{l}\text { Nomination } \\
\text { Risk management }\end{array}$ & 3 & $\begin{array}{l}\text { Independent } \\
\text { chairman }\end{array}$ & 2 & Ethnic & 3 \\
\hline Sharia & 1 & & & & \\
\hline Remuneration & 2 & & & & \\
\hline $\begin{array}{l}\text { Governance } \\
\text { index }\end{array}$ & 12 & & & & \\
\hline
\end{tabular}

